TITLE:

\title{
Structural characteristics of alkylimidazolium-based salts containing fluoroanions
}

$\operatorname{AUTHOR}(S)$ :

Matsumoto, Kazuhiko; Hagiwara, Rika

\section{CITATION:}

Matsumoto, Kazuhiko ... [et al]. Structural characteristics of alkylimidazolium-based salts containing fluoroanions. Journal of Fluorine Chemistry 2007, 128(4): 317-331

ISSUE DATE:

2007-04

URL:

http://hdl.handle.net/2433/251199

\section{RIGHT:}

(c) 2007. This manuscript version is made available under the CC-BY-NC-ND 4.0 license

http://creativecommons.org/licenses/by-nc-nd/4.0/; The full-text file will be made open to the public on 1 April 2009 in accordance with publisher's 'Terms and Conditions for Self-Archiving'; この論文は出版社版でありません。引用の際に は出版社版をご確認ご利用ください。; This is not the published version. Please cite only the published version. 
Structural characteristics of alkylimidazolium-based salts containing fluoroanions

Kazuhiko Matsumoto, ${ }^{\text {a, b, * }}$ Rika Hagiwara ${ }^{a}$

a Graduate School of Energy Science, Kyoto University, Yoshida, Sakyo-ku, Kyoto 606-8501, Japan

b Present address: Department of Chemistry, McMaster University, 1280 Main Street, Hamilton, Ontario L8S 4M1, Canada

* E-mail: matsumk@mcmaster.ca

Key words: Ionic liquid, Structure, Room temperature ionic liquid; Room temperature molten salt, Fluoroanion, Alkylimidazolium 


\begin{abstract}
An overview of recent structural studies on alkylimidazolium-based salts containing fluoroanions is presented. Alkylimidazolium cations have been most extensively used for syntheses of ionic liquids (room temperature molten salts) because they usually exhibit low melting points, low viscosities and high conductivities. This review is focused on structures of alkylimidazolium-based salts combined with fluorocomplex $\left(\mathrm{FHF}^{-}, \mathrm{BF}_{4}^{-}\right.$, $\left.\mathrm{PF}_{6}{ }^{-}, \mathrm{AsF}_{6}{ }^{-}, \mathrm{SbF}_{6}{ }^{-}, \mathrm{NbF}_{6}{ }^{-}, \mathrm{TaF}_{6}{ }^{-}\right)$and bis(trifluoromethylsulfonyl)amide $\left(\mathrm{N}\left(\mathrm{SO}_{2} \mathrm{CF}_{3}\right)_{2}{ }^{-}\right.$ or $\mathrm{TFSI}^{-}$) anions. The former part describes crystal structures of these salts and the latter part describes computational, spectroscopic and diffraction studies on their liquid structures. Related studies on ionic liquids of non-alkylimidazolium cation and non-fluoroanion are also briefly summarized.
\end{abstract}




\section{Introduction}

It has passed more than ten years since the concept of ionic liquid was widely accepted. In the history, the finding of ethylammonium nitrate (m.p. 285 K) by Walden in 1914 opened up this field [1], which did not attract much attention those days. In 1970s and 80s halogenoaluminate ionic liquids were studied mainly in the field of electrochemistry [2-5]. In 1990s, a number of moisture-stable ionic liquids, most of them containing fluorine, were synthesized and characterized [2, 6-15]. Since ionic liquids are nonvolatile at ambient conditions, nonflammable and ionically conductive in wide temperature range, the use of ionic liquids immediately spread into various fields such as electrochemistry $[6,7,16]$, synthetic and catalytic chemistry $[2,8-15]$. Today, the term "ionic liquid" is widely used in the same meaning as the term "room temperature molten salt" or "ambient temperature molten salt” usually containing organic cation, but the term itself was already seen in the old literature and the meaning was "liquid made of only ions regardless of temperatures,” different from the definition today $[17,18]$.

Although various kinds of organic cations are known to form ionic liquids, alkylimidazolium salts have occupied center stage in this field, because they usually exhibit low melting points and low viscosities that normally lead to high conductivities. These excellent properties of alkylimidazolium-based salts are often explained by charge delocalization on the aromatic five-membered ring (Fig. 1).

Various kinds of ionic liquids containing fluoroanions are comprehensively reviewed in a recent paper by $\mathrm{H}$. Xue et al. [8]. The higher stability of fluoroanion-based ionic liquids in the air enabled their use in various fields. The partial structures of ionic liquids, which are often discussed in terms of "ion pair" or "aggregate” of molecular level, give conceivable explanations for various reactions in ionic liquids and electrochemical 
processes as well as physical properties. In the longer history of chloro- or bromocomplex salts, many efforts have been made to elucidate their structural properties, whereas the invention of the ionic liquid containing a fluoroanion, $\mathrm{EMImBF}_{4}(\mathrm{EMIm}=$ 1-ethyl-3-methylimidazolium), was made in 1992 [19] and therefore their structural characteristics have been rapidly reported for the recent ten years. This review is focused on structural characteristics of alkylimidazolium-based salts especially containing fluoroanions.

\section{Crystal structures of alkylimidazolium-based salts containing fluoroanions}

One of the common approaches to study the structure of an ionic liquid is to start from its solid state structure. Table 1 gives selected crystallographic data and melting points of alkylimidazolium-based salts which contain fluoroanions. Abbreviation for the name of ion used in the present review is also summarized in the footnote of Table 1.

\subsection{Fluorocomplex salts}

As is found in some literature [20-22], alkylimidazolium salts of naked fluoride ion, $\mathrm{F}^{-}$, are unstable at ambient conditions. The monohydrate salt, $\mathrm{BMImF} \cdot \mathrm{H}_{2} \mathrm{O}(\mathrm{BMIm}=$ 1-butyl-3-methylimidazolium), was obtained as a crystalline decomposition product from the hydrolytic degradation of $\mathrm{BMImPF}_{6}$ [23]. In $\mathrm{BMImF} \cdot \mathrm{H}_{2} \mathrm{O}, \mathrm{BMIm}^{+}$cations associate as dimers via overlapping alkyl tails. The dimers also make up the parallel sides of a box. Hydrogen bonds are observed between the hydrogen atoms of the cation or $\mathrm{H}_{2} \mathrm{O}$ and $\mathrm{F}^{-}$.

In $\mathrm{DMImPF}_{6}(\mathrm{DMIm}=$ 1,3-dimethylimidazolium), DMIm cations form a weakly hydrogen bonded zigzag chain motif via methyl hydrogen atoms and $\pi$-electron [24]. Hexafluorophosphate anions are located between these chains and make closest contacts 
with methyl hydrogen atoms. This structure was compared to the $\mathrm{DMImPF}_{6} \cdot 0.5 \mathrm{C}_{6} \mathrm{H}_{6}$ (benzene) which was isolated on cooling the molten 1:2 DMImPF6-benzene liquid clathrate [24]. In $\mathrm{DMImPF}_{6} \cdot 0.5 \mathrm{C}_{6} \mathrm{H}_{6}$, the benzene molecules do not interact with one another and are isolated within channels resulting from three-dimensional hydrogen bonding network. The structure of $\mathrm{DMImPF}_{6}$-benzene mixtures in the liquid state was studied by neutron diffraction based on this result [25].

Structures of a series of EMIm fluorocomplex salts were successively reported after the report on the structure of $\mathrm{EMImPF}_{6}$ [26]. Figure 2 shows the layered structure of EMImFHF which contains the smallest fluorocomplex anion $\mathrm{FHF}^{-}$in the series [27], and was studied as a structural model of a series of highly conductive ionic liquids, RMIm(FH)2.3F (RMIm: 1-alkyl-3-methylimidazolium) [28-32]. The flat imidazolium rings are stacked and arranged in parallel with the interlayer distance of $3.376 \AA$ which is close to the van der Waals layer separation found in the graphite structure (3.35 $\AA$ ). In each layer, very short hydrogen bond distances between ring $\mathrm{H}$ atom of the cation and $\mathrm{F}$ atom of the anion (1.951, 2.166 and $2.226 \AA$ ) are observed. They are comparable to those observed in BMImF· $\mathrm{H}_{2} \mathrm{O}$ (1.96, 2.07, 2.31 and $2.44 \AA$ ) [23]. A similar layered structure with an interlayer distance of $3.381 \AA$ was reported for $\mathrm{EMImNO}_{2}$ which contains a little bigger and bent $\mathrm{ONO}^{-}$anion [19]. In the EMImBF 4 structure, EMIm cations form a pillar with the $\beta$-carbon of the ethyl group sticking out of the imidazolium-ring plane [33,34]. The $\mathrm{H}$ (methylene) $\cdots \pi$ interaction sustains the cation-cation interactions with a contact distance of $2.86 \AA$ between the $\mathrm{H}$ atom in methylene group and the imidazolium ring centroid. A similar $\mathrm{H}$ (methylene) $\cdots \pi$ contact $(2.86 \AA)$ was also found in the (EMIm) ${ }_{2} \mathrm{PtCl}_{6}$ structure [35]. Tetrafluoroborate anions also form a pillar along the $b$-axis. For EMIm salts of hexafluorocomplex anions, EMImAsF 6 and EMImSbF$_{6}$ are 
isostructural with $\mathrm{EMImPF}_{6}[21,26]$, whereas $\mathrm{EMImNbF}_{6}$ and $\mathrm{EMImTaF}_{6}$ exhibit a different structure [33]. Figure 3 shows the ion packings in EMImAsF6 and EMImNbF6. In the $\mathrm{EMImAsF}_{6}$ structure, $\mathrm{EMIm}^{+}$and $\mathrm{AsF}_{6}{ }^{-}$stack alternately along the $b$-axis to form pillars. On the other hand, in the $\mathrm{EMImNbF}_{6}$ structure, the anion appears in a zigzag arrangement along the $a$-axis where the nearest fluorine atoms have a distance of $3.441 \AA$ (for F5 $\cdots$ F2) and the cations adopt a pillar-like stacking along the same axis. In spite of closer $\mathrm{H}^{\cdots}$ F contacts in $\mathrm{EMImNbF}_{6}$ and $\mathrm{EMImTaF}_{6}$ than those in $\mathrm{EMImPF}_{6}, \mathrm{EMImAsF}_{6}$ and $\mathrm{EMImSbF}_{6}$, the melting points of the former two compounds are much lower than those of the latter three compounds. $\mathrm{EMImBF}_{4}$ also exhibits a low melting point despite relatively strong hydrogen bonds in its lattice. These observations suggest that the strength of hydrogen bonding is not always a decisive factor in their melting points. [EMImBF4 の記述これだけですか？ 図もなし論文の引用もなし］[“5ページ下から6 行目“に記述されておりますが、足りませんでしようか。]

Only one crystal structure is known so far for BMIm fluorocomplex salt $[34,36]$. BMImPF6, whose structure is most extensively studied by various methods, contains two types of interplanar arrangements of imidazolium cations; in one set, the butyl groups point into the space between the imidazolium rings, and in the other they point outwards. These pairs propagate continuously in the $\mathrm{BMImPF}_{6}$ structure. There are no close $\pi$ - $\pi$ interactions between the imidazolium rings. The $\mathrm{PF}_{6}$ anions are positioned close to the imidazolium rings and lie in the channels between the imidazolium rings and butyl chains. Existence of some hydrogen bonds was confirmed between $\mathrm{H}$ atoms of the cation and $\mathrm{F}$ atom of the anion in the lattice.

Crystal structures of a series of BDMIm (BDMIm = 1-butyl-2,3-dimethylimidazolium) salts combined with $\mathrm{BF}_{4}^{-}, \mathrm{PF}_{6}{ }^{-}$and $\mathrm{SbF}_{6}{ }^{-}$were determined as structural models for ionic 
liquids [37]. In BDMIm ${ }^{+}$, methyl group is substituted for the most acidic C2 hydrogen atom. All the three salts have significantly different structures and $\mathrm{BDMIm}^{+}$adopts different conformations in the different compounds with respect to the butyl chain that sticks out of the plane of the imidazolium ring. In $\mathrm{BDMImBF}_{4}$, both the two crystallographically independent $\mathrm{BF}_{4}$ anions are disordered at $213 \mathrm{~K}$. This structure can be described as being composed of two different types of double layers. The anionic parts of these two layers are very similar, whereas the cationic part is markedly different for the two double layers. None of the ring hydrogen atoms shows an orientation which would suggest hydrogen bonding to the $\mathrm{F}$ atom in $\mathrm{BF}_{4}^{-}$. Crystal structure of BDMImPF6 is composed of alternating layers of cations and anions extending in the crystallographic (011) plane, with all imidazolium ring planes coplanar (roughly perpendicular to the $a$-axis) and all butyl chains aligned in one direction, roughly parallel to the $a$-axis. The $\mathrm{PF}_{6}{ }^{-}$ordered at $213 \mathrm{~K}$ but disordered at $298 \mathrm{~K}$ is surrounded by six cations with the centers forming a distorted trigonal prism. No disorder is observed for the BDMImSbF6 structure even at ambient temperature. The cation and anion arrangement in BDMImSbF6 is reminiscent of NiAs-type structure with the $\mathrm{SbF}_{6}$ anions surrounded by six nearest neighbor cations in a distorted trigonal prismatic coordination and the cations surrounded by six $\mathrm{SbF}_{6}$ anions in a distorted octahedral arrangement. There are no short contacts between carbon atoms of the butyl chains, and thus short-range repulsive interactions between the cations are further diminished with respect to the $\mathrm{PF}_{6}$ salt. Structures of BDMIm salts of other non-fluoroanions were also discussed in another paper by the same authors as well as their hydrogen bonding properties [38].

Solid-state structure models for ionic liquids containing fluorocomplex anions have been reported for $(\mathrm{MBz})_{2} \operatorname{Im}\left((\mathrm{MBz})_{2} \operatorname{Im}=1,3-\mathrm{di}-R-(+)\right.$-methylbenzyl-imidazolium) salts 
[39]. Crystallographic structures of the two salts $(\mathrm{MBz})_{2} \operatorname{ImBF}_{4}$ and $(\mathrm{MBz})_{2} \operatorname{ImPF}_{6}$ are similar, where the cation is surrounded by six anions in both the salts and three of the six are through ring hydrogen atoms. These structures resemble the $\mathrm{BMImBPh}_{4}\left(\mathrm{BPh}_{4}=\right.$ tetraphenylborate) structure [40]. As shown in Fig. 4, cations form network structure in the lattice in which anions are accommodated as chains along the $a$-axis for $(\mathrm{MBz})_{2} \mathrm{ImBF}_{4}$ and along the $b$-axis for $(\mathrm{MBz})_{2} \mathrm{ImPF}_{6}$. The $\mathrm{BF}_{4}^{-}$leads to slightly longer $\mathrm{C}-\mathrm{H} \cdots \mathrm{F}$ bonds with respect to the $\mathrm{PF}_{6}{ }^{-}$, while in the $\mathrm{PF}_{6}$ salt the $\mathrm{C}-\mathrm{H}$ donors approach more linearly toward the $\mathrm{F}$ atom. There are relatively important hydrogen bonds between the methyl group of the benzylic moiety and the F atoms. The authors concluded that the monomeric unit, constituted by at least one cation surrounded by three anions and vice versa, is apparently independent of the nature of imidazolium substituents or on the type of anion (halogen, $\mathrm{BF}_{4}, \mathrm{PF}_{6}, \mathrm{BPh}_{4}$, etc.) and that the general structural organization of the imidazolium salts in the solid state can be represented as $\left\{\left[(\mathrm{DAI})_{3}(\mathrm{X})\right]^{2+}\left[(\mathrm{DAI})(\mathrm{X})_{3}\right]^{2-}\right\}_{\mathrm{n}}$, where DAI is the dialkylimidazolium cation and $\mathrm{X}$ is the anion.

A series of alkylimidazolium salts with nitrile functional group to the alkyl side-chain were reported, where crystal structures of two $\mathrm{PF}_{6}$ salts, $\mathrm{PNMIm}^{+} \mathrm{PF}_{6}{ }^{-}(\mathrm{PNMIm}=$ 1-methyl-3-propylnitrileimidazolium) $\quad$ and $\quad$ PNDMIm $^{+} \mathrm{PF}_{6}^{-} \quad$ PNDMIm $^{-}=$ 1,2-dimethyl-3-propylnitrileimidazolium) were determined [41]. The compound, $\mathrm{PNMIm}^{+} \mathrm{PF}_{6}{ }^{-}$, contains a short $\mathrm{C} 2-\mathrm{H} \cdots \mathrm{F}$ contact of $2.43 \AA$ and some other weak hydrogen bonds, whereas $\mathrm{PDMMIm}^{+} \mathrm{PF}_{6}{ }^{-}$also contains a short $\mathrm{C} 5-\mathrm{H} \cdots \mathrm{F}$ contact of 2.49 $\AA$ although $\mathrm{PNDMIm}^{+} \mathrm{PF}_{6}{ }^{-}$does not have the acidic $\mathrm{C} 2$ hydrogen atom.

A structural model is reported for ferrocene-containing ionic liquids [42]. In the structure of $\quad(\mathrm{DMImMCp})_{2} \mathrm{Fe}^{2+}\left(\mathrm{PF}_{6}^{-}\right)_{2} \quad\left((\mathrm{DMImMCp})_{2} \mathrm{Fe}^{2+}=\right.$ 1,1'-bis\{[1-(2,3-dimethyl)imidazolium]methyl $\}$ ferrocene), the Cp-Fe-Cp angle is $180^{\circ}$ 
and the substituents on the $\mathrm{Cp}$ ring has a trans-arrangement. The $\mathrm{PF}_{6}{ }^{-}$is separated from the ferrocenyl cation.

One of the interesting applications of ionic liquids is their use as liquid crystalline materials [43-47]. Crystal structures of dialkylimidazolium salts with long alkyl side-chains provide structural models for ionic liquid crystals. [液晶はそれ自体が結晶 ですからその結晶構造が液晶構造モデルを与えるというのは変ではないでしよ うか。液晶の構造そのものですから。] [液晶を作るより低温の固体結晶構造が液 晶状態の構造モデルとなるという意味なのですが、おかしいでしょうか。]液晶 がさらに別の構造の結晶になるのですか？] [相転移がなければ固体結晶 $\rightarrow$ 液晶 ↔液体ではないのでしょうか。実際には下記の C12MImPF6 塩は液晶にならず、 単に結晶から液体になり、C14MIm, C16Im, C18ImPF6 塩が液晶相（スメクティッ ク相）を作ると記述されています。]. The crystal structure of $\mathrm{C}_{12} \mathrm{MImPF}_{6}\left(\mathrm{C}_{12} \mathrm{MIm}=\right.$ 1-dodecyl-3-methylimidazolium), which was reported in the study on a series of alkylimidazolium and alkylpyridinium-based ionic liquid crystalline materials, consists of discrete cations and anions separated by at least van der Waals distances [43]. The straight chain of the alkyl group is disrupted close to the ring where it takes a bent conformation to exhibit a spoon-shaped structure. The chain configuration and the lack of any disorder in the structure appear to be a consequence of the interdigitated molecular packing. As is often found for liquid crystalline salts, sheets of imidazolium rings and PF6 anions are separated by interdigitate alkyl chains (Fig. 5) with the spacing of 22.197(4) $\AA$ between the layers. According to X-ray powder diffraction studies for $\mathrm{RMImPF}_{6}\left(\mathrm{R}=\mathrm{C}_{12}, \mathrm{C}_{14}, \mathrm{C}_{16}\right.$ and $\mathrm{C}_{18}$, where the subscript number represents the number of carbon atoms in the alkyl chain), all of them have similar layered structures and the 
interlayer distance increases regularly with increasing the length of alkyl chain. The following study revealed that $\mathrm{C}_{14} \mathrm{MImPF}_{6}$ had a similar structure to $\mathrm{C}_{12} \mathrm{MImPF}_{6}$ and a phase transition occurs at $278 \mathrm{~K}$ [44]. The phase transition does not involve a major structural change but is largely marked by an increase in the degree of motion in the anion and the alkyl chain on the cation. Studies on ionic liquid crystals were summarized in a recent review [47].

\section{$2.2 \mathrm{~N}\left(\mathrm{SO}_{2} \mathrm{CF}_{3}\right)_{2}{ }^{-}, \mathrm{OSO}_{2} \mathrm{CF}_{3}{ }^{-}$and $\mathrm{BARF}^{-}$salts}

Bis(trifluoromethylsulfonyl)amide anion $\left(\mathrm{N}\left(\mathrm{SO}_{2} \mathrm{CF}_{3}\right)_{2}{ }^{-}\right.$or $\left.\mathrm{TFSI}^{-}\right)$has been used as a counter ion of lithium salt, LiTFSI [48], a supporting electrolyte of lithium (ion) batteries. It is one of the most popular anions for syntheses of ionic liquids that gives hydrophobic salts with low melting point, low viscosity and high electrical conductivity. The hydrophobicity is one of the important properties for non-distillable ionic liquids which makes purifying and drying process easier by solvent extraction. A series of alkylimidazolium salts combined with $\mathrm{TFSI}^{-}$were first reported in 1996 [49], followed by various TFSI--based ionic liquids [50-52].

The compound, EMBzImTFSI (EMBzIm = 1-ethyl-2-methyl-3-benzyl-imidazolium), is the first TFSI salt which is related to ionic liquids whose structure has been determined by single-crystal X-ray diffraction [53]. In the EMBzImTFSI structure, $\mathrm{TFSI}^{-}$takes a trans-conformation and no strong hydrogen bonds between the cation and anion are observed. The S-N bond lengths of the anion in EMBzImTFSI (1.56-1.57 $\AA$ ) are significantly shorter than typical S-N single bonds $(\sim 1.75 \AA)$ as a result of the S-N-S charge delocalization. The key feature of this anion in promoting a low melting point in its compounds, concomitant with high fluidity, seems to be this charge delocalization 
coupled with the lack of hydrogen bonding. As in the case of EMBzImTFSI, the $\mathrm{Me}_{3} \mathrm{NBH}_{2} \mathrm{MImTFSI}\left(\mathrm{Me}_{3} \mathrm{NBH}_{2} \mathrm{MIm}=(N\right.$-methylimidazole $)($ trimethylamine $)$ boronium $)$ which is the first structural model of ( $N$-alkylimidazole)(amine)boronium-based ionic liquids contains the disordered TFSI anions with trans-conformation and only weak intermolecular contacts exist in the lattice [54].

In DMImTFSI, both the two crystallographically distinct TFSI anions adopt a cis-conformation [55]. The crystal lattice of DMImTFSI consists of alternating two-dimensional sheets with an -AA-B-AA- pattern comprised of charge-bearing double layers of cations and anions separated by fluorous regions formed by the $\mathrm{CF}_{3}$ groups on the anions. In the charged planes, the $\mathrm{TFSI}^{-}$is hydrogen-bonded to three equatorially arrayed 1,3-dimethylimidazolium cations through $\mathrm{C}-\mathrm{H} \cdots \mathrm{O}$ and $\mathrm{C}-\mathrm{H} \cdots \mathrm{N}$ contacts (Fig. 6) and to an additional imidazolium cation below each anion. Another structural model for TFSI-based salts is TEImTFSI (TEIm = 1,2,3-triethylimidazolium). The TEImTFSI structure consists of alternating layers of TEIm ${ }^{+}$cations and trans-TFSI anions with only weak cation-anion interactions [55]. The cis-conformation of $\mathrm{TFSI}^{-}$has a higher energy than the trans-conformation and therefore the cis-conformation is observed only in the compounds where strong interaction between the cation and anion forces this conformation [55,56]. In DMImTFSI, hydrogen bond between ring hydrogen atoms of the cation and $\mathrm{O}$ atoms of the anion stabilizes the cis-conformation of the anion. TEImTFSI contains fewer hydrogen bonds than DMImTFSI and the cation adopts a trans-conformation.

An equimolar inclusion compound of EMImTFSI and benzene, EMImTFSI $\mathrm{C}_{6} \mathrm{H}_{6}$, obtained from their mixture was characterized by single-crystal X-ray diffraction [57]. The interactions between the anion and the benzene molecule occur mainly between the 
hydrogen atoms of the latter and the oxygen atoms of the sulfonyl groups of the former. Interactions with the fluorine atoms of the anion are also present at a lesser extent. As in the case of $\mathrm{DMImPF}_{6}$, the anions cluster around the benzene molecule mainly in the plane of the aromatic ring and the interactions occur in that plane. The interactions between the imidazolium cations and benzene are mainly $\pi-\pi$ interactions between aromatic rings or interactions between the acidic hydrogens in the cation and the $\pi$-electrons of benzene, i.e. the cations occupy positions above and below the plane of the benzene aromatic ring. Some parts of this crystal structure resemble the structure of DMImTFSI shown above. However, the ionic network is more expanded in the case of the inclusion compound (it has to accommodate for the presence of the benzene molecules). Nevertheless, it manages to preserve a significant amount of its ion pair interactions.

The TFSI salt, EtOC(O)CEtImTFSI $\quad($ EtOC $(\mathrm{O})$ CetIm $=$ 1-(1-(R)-Ethoxycarbonyl-ethyl)-3-methyl-imidazolium), is the first structural model of chiral ionic liquids [58]. Interestingly, a complete racemisation was observed for this compound. The $\mathrm{TFSI}^{-}$adopts a cis-conformation and two $\beta$-carbon atoms of the cation are sticking out of the imidazolium plane. Cations are surrounded by three TFSI anions and through some strong hydrogen bonds between hydrogen atoms of the cation and $\mathrm{O}$ or $\mathrm{N}$ atoms of the anion.

Crystal structure of $\mathrm{Li}_{2}(\mathrm{EMIm})(\mathrm{TFSI})_{3}$ was determined as a structural model for ionic liquid electrolytes for lithium (ion) batteries [59]. Two of the three TFSI anions have cis-conformations and the third anion shows a trans-conformation. Both the crystallographically independent Li cations are trigonal-bipyramidally coordinated by the five oxygen atoms of the anions, and no coordination by other atoms such as nitrogen is 
observed. Although bidentate coordination was observed in both the cases, the two O atoms in the bidentate conditions are bound to different sulfur atoms on the same anion. The complicated $\mathrm{Li} \cdots \mathrm{O}$ local interactions construct a two-dimensional network and $\mathrm{EMIm}^{+}$occupies a space in the network structure, weakly interacting with the anion. As a result of $\mathrm{Li}^{+}$-TFSI ${ }^{-}$interactions, fluorine atoms on the $\mathrm{CF}_{3}$ group form a so-called fluorous region.

Two examples of the crystal structures of alkylimidazolium salts containing $\mathrm{OSO}_{2} \mathrm{CF}_{3}{ }^{-}$ (triflate anion) were reported. In the layered structure of $\mathrm{BMImOSO}_{2} \mathrm{CF}_{3}$ [34], imidazolium ring of the cation and $\mathrm{SO}_{3}$-group of the anion are connected by hydrogen bond to form a two dimensional NaCl-like arrangement in each layer. The butyl group of the cation and the $\mathrm{CF}_{3}$ group of the anion are sticking out of the layer to the same direction. The layer stacks on the adjacent layer to have NaCl-type arrangement of the ions, but the butyl and $\mathrm{CF}_{3}$ groups are sticking to the opposite direction. Therefore, this structure contains a hydrophobic layer made of the butyl and $\mathrm{CF}_{3}$ group sandwiched between the two layers. The structure of $\mathrm{DBImOSO}_{2} \mathrm{CF}_{3}$ (1,3-di-tert-butylimidazolium) obtained by the reaction of $\left[\mathrm{Zn}(t-\mathrm{BuNCHCHN}-t-\mathrm{Bu})_{2}\right]\left(\mathrm{OSO}_{2} \mathrm{CF}_{3}\right)_{2}$ and methanol was also reported in another paper [60].

$$
\text { BMImBARF (BARF }=\text { tetrakis(3,5-bis(trifluoromethyl)phenyl)borate) is a }
$$
dialkylimidazolium salts containing tetraarylborate anion [61]. There is a typical disorder in the trifluoromethyl groups in the BARF ${ }^{-}$. The $n$-butyl chain of the imidazolium cation is also disordered. There appears to be no hydrogen bond interactions between the $\mathrm{H}$ atom of cation and the $\pi$-electron of $\mathrm{BARF}^{-}$, which was observed in $\mathrm{BMImBPh}_{4}$, as the bulky trifluoromethyl moieties prevent the anion and cation from coming into close enough proximity for such interactions to occur [40]. 


\subsection{Related studies}

Structural studies of alkylimidazolium salts containing non-fluoroanions are briefly summarized here. Crystal structures of some halide salts which are often used as starting materials to synthesize ionic liquids have been determined [38, 62-71]. Structures of alkylimidazolium chlorocomplex and oxychlorocomplex salts in solid states are known; $\mathrm{AlCl}_{4}{ }^{-}$[72] $\mathrm{CoCl}_{4}{ }^{2-}, \mathrm{NiCl}_{4}{ }^{2-}$ [73], $\mathrm{PtCl}_{4}{ }^{2-}, \mathrm{PtCl}_{6}{ }^{2-}, \mathrm{IrCl}_{6}{ }^{2-}$ [35], $\mathrm{PdCl}_{4}{ }^{2-}$ [74], $\mathrm{PdCl}_{4}{ }^{2-} \cdot \mathrm{H}_{2} \mathrm{O}$ [75], $\left[\mathrm{SnCl}_{3}^{-}\right]\left[\mathrm{Cl}^{-}\right][76], \mathrm{AuCl}_{4}^{-}$[77], $\mathrm{LaCl}_{6}^{3-}$ [78], $\left[\mathrm{FeCl}_{4}{ }^{2-}\right]\left[\mathrm{FeCl}_{4}^{-}\right]_{2}$ [38], $\mathrm{Cu}_{3} \mathrm{Cl}_{8}^{-}$[79], $\mathrm{BiCl}_{4}^{-}$[80], $\mathrm{VOCl}_{4}{ }^{2-}$ [81], $\mathrm{UCl}_{6}{ }^{2-}$ and $\mathrm{UO}_{2} \mathrm{Cl}_{4}{ }^{2-}$ [82]. Structural data of the alkylimidazolium salts of the following anions, $\mathrm{AlBr}_{4}^{-}$[65], $\mathrm{Ru}_{2} \mathrm{Br}^{3-}{ }^{3}$ [83], $\mathrm{Ag}(\mathrm{CN}) 2^{-}$[84], $\mathrm{NO}_{3}^{-}, \mathrm{NO}_{2}^{-}$[19], $\mathrm{CH}_{3} \mathrm{SO}_{4}^{-}$[85], $\mathrm{HSO}_{3}^{-}$[38] $\mathrm{RB}_{11} \mathrm{X}_{\mathrm{mH}} \mathrm{H}^{-}$(R: alkyl, X: $\mathrm{Br}$ or I) [86], $\mathrm{SO}_{4}{ }^{2-} \cdot \mathrm{H}_{2} \mathrm{O}[19], \mathrm{S}_{2} \mathrm{O}_{7}{ }^{-}[87], \mathrm{BPh}_{4}{ }^{-}[39,40], \mathrm{UO}_{2}\left(\mathrm{NO}_{3}\right)_{4}{ }^{2-}, \quad\left[\left\{\mathrm{UO}_{2}\left(\mathrm{NO}_{3}\right)_{2}\right\}_{2}\left(\mu-\mathrm{C}_{2} \mathrm{O}_{4}\right)\right]^{2-}$, $\left[\left\{\mathrm{UO}_{2}\left(\mathrm{NO}_{3}\right)_{2}\right\}_{2}\left(\mu-\mathrm{C}_{2} \mathrm{O}_{4}\right)\right]^{2-} \cdot \mathrm{NO}_{3}{ }^{-}$and $\left[\left\{\mathrm{UO}_{2}\left(\mathrm{NO}_{3}\right)_{2}\right\}_{2}\left(\mu-\mathrm{C}_{2} \mathrm{O}_{4}\right)\right]^{2-} \cdot$ (ethanenitrile) [88] are also available.

Nonaromatic heterocyclic cation, such as alkylpyrrolidinium and alkylpiperidinium as well as linear tetra-alkylammonium have attracted attention due to the needs of more chemically and electrochemically stable compounds [16,89-91]. Compared to the cases of aromatic cations, nonaromatic cation-based salts generally exhibit higher melting points. However, room temperature ionic liquids are obtained when they are combined with some suitable anions such as $\mathrm{TFSI}^{-}$. Some nonaromatic cation-based salts of $\mathrm{PF}_{6}{ }^{-}$ [92], $\mathrm{TFSI}^{-}[93,94], \mathrm{N}\left(\mathrm{SO}_{2} \mathrm{CH}_{3}\right)_{2}^{-}$[95] and $\mathrm{SCN}^{-}$[96] related to ionic liquids are characterized by single crystal X-ray diffraction.

\section{Computational, spectroscopic and diffraction studies on liquid structures of}




\section{alkylimidazolium-based salts containing fluoroanions}

While the solid-state structures of the compounds related to ionic liquids are studied to give a clue to their liquid structures, a number of studies using computational, spectroscopic and diffraction methods have also been made by many groups. Since an ionic liquid usually contains a large organic cation which is not in a simple spherical shape, local ion-ion interactions in the liquid state are not straightforward. Table 2 summarizes the computational, spectroscopic and diffraction studies on ion-ion interactions and liquid structures of alkylimidazolium-based ionic liquids containing fluoroanions. Abbreviations for the names of ions which do not appear in Table 1 are given in the footnote of Table 2 .

\subsection{Computational approaches}

Molecular dynamics (MD) and Monte-Carlo simulations are popular methods to study the structures of ionic liquids. Although these studies usually include important computational details necessary for the simulations such as a force-field [97-99], only the results of ion-ion interactions obtained from the simulations are mainly summarized in this part. The results of $\mathrm{MD}$ simulations on $\mathrm{EMImBF}_{4}$ and $\mathrm{BMImBF}_{4}$ as well as $\mathrm{EMImAlCl}_{4}$ and $\mathrm{BMImAlCl}_{4}$ suggest that the local structural features are strongly affected by the nature of the anion $[100,101]$. The cation-anion radial distribution functions (RDF) show a more defined first solvation sphere of anions around the cations and vice versa in the $\mathrm{BMIm}^{+}$-based ionic liquids than that in $\mathrm{EMIm}^{+}$-based ionic liquids.

$\mathrm{BMImPF}_{6}$ is the most experimentally studied ionic liquid to date and is the most simulated system as well. Monte-Carlo simulation for $\mathrm{BMImPF}_{6}$ using a united atom force field combined with $a b$ initio calculation suggest that cation-anion pairs tend to 
order in a first solvation shell at a separation of about $4 \AA$ [102]. Subsequent cation-anion solvation shells occur at 10 and $17 \AA$. Long range order persists even out beyond $20 \AA$, as evidenced by the fact that the RDF still shows oscillations. Such a long range order is not observed for non-polar liquids, but is expected here, due to the strong Coulombic interactions in the system. The anion tends to associate with the C2 hydrogen atom of the cation. A similar distribution of anion was observed in the Monte-Carlo simulation of DMImPF6 [103]. Radial distribution function obtained by MD simulations of BMImPF6 shows the presence of quite a long spatial correlation of more than $20 \AA$ [104]. The cation-anion correlation has a sharp peak at around $4.2 \AA$ (C2-P distance) and appears to be stronger than cation-cation and anion-anion correlations. Another report on the same system using MD simulations gives similar RDFs [105,106]. In addition, comparison of the results of simulations using two united atom force fields and one all atom force-field shows that the RDFs based on each force-field differ from each other (Fig. 7 copyright) [107]. All the three force fields show a strong localization of the anion about the C2 carbon, whereas the localization states of the anion about the other two ring hydrogen atoms, C4 and C5, depend on the choice of the force-field. Another simulation for $\mathrm{BMImPF}_{6}$ which gives similar RDFs to those above, suggest that a ring $\pi$ - $\pi$ stacking exists and the conformation of the butyl chain has three minima in the potential energy fucntion at the N1-C7-C8-C9 dihedral angle of 180, -60 , and +60, corresponding to one trans and two equivalent gauche conformers [108].

Ionic conductivities of a series of BMIm-based ionic liquids combined with fluorinated organic anions $\left(\mathrm{CF}_{3} \mathrm{COO}^{-}, \mathrm{C}_{3} \mathrm{~F}_{7} \mathrm{COO}^{-}, \mathrm{CF}_{3} \mathrm{SO}_{3}{ }^{-}\right.$, and $\left.\mathrm{C}_{4} \mathrm{~F}_{9} \mathrm{SO}_{3}{ }^{-}\right)$as well as $\mathrm{PF}_{6}{ }^{-}$were investigated by MD simulations [109]. The result shows that the self-diffusion coefficient is an important factor in determining the conductivity of ionic liquid. The 
RDF for $\mathrm{BMImPF}_{6}$ shows that two solvation shells are located at 4.4 and $10.8 \AA$, whereas the first solvation shell was located at a greater distance and the second solvation shell was located at 10-12 $\AA$ for the other ionic liquids containing fluorinated organic anions.

Geometries of the isolated ions and ion pairs were calculated by molecular mechanics and $a b$ initio methods for ionic liquids composed of alkylimidazolium cations (DMIm ${ }^{+}$, $\mathrm{EMIm}^{+}$and $\left.\mathrm{BMIm}^{+}\right)$and fluorocomplex anions $\left(\mathrm{BF}_{4}^{-}\right.$and $\left.\mathrm{PF}_{6}{ }^{-}\right)$[110]. The geometry of $\mathrm{DMIm}^{+}-\mathrm{PF}_{6}{ }^{-}$ion pair has an asymmetric structure with the $\mathrm{H} \cdots \mathrm{F}$ interaction via both $\mathrm{H}$ atoms of the imidazolium ring and alkyl side-chain. Similar geometries are also obtained for $\mathrm{EMIm}^{+}-\mathrm{BF}_{4}^{-}$and $\mathrm{BMIm}^{+} \mathrm{PF}_{6}{ }^{-}$ion pairs. This kind of model was also observed in other $a b$ initio or DFT calculations [111-113]. Molecular mechanics based on the proposed force-field by the authors give similar results to those from the $a b$ initio calculations by the adjustment of some parameters. Molecular dynamics simulation for $\mathrm{BMImPF}_{6}$ using the same force field results in a little different cation-anion RDF from those described above, giving the two solvation cell located at 4.8 and $11.0 \AA$ which are longer than those in other reports. The RDFs for $\mathrm{F}$ atom of $\mathrm{PF}_{6}{ }^{-}$and $\mathrm{H}$ atoms of $\mathrm{BMIm}^{+}$ indicate that the order of hydrogen bonding activities of the different $\mathrm{H}$ atoms on the $\mathrm{C}$ atoms in the cation is $\mathrm{H} 2>\mathrm{H} 4, \mathrm{H} 5>\mathrm{H} 6>\mathrm{HC}$, where $\mathrm{H} 6$ denotes $\mathrm{H}$ atoms in the butyl chain bound to $\mathrm{N}$ atom and $\mathrm{HC}$ denotes the other $\mathrm{H}$ atoms in the butyl chain. Comparison of the results for various anions reveals that the interaction between the C2 hydrogen atom and $\mathrm{X}\left(\mathrm{X}=\mathrm{Cl}^{-}\right.$or $\mathrm{F}$ atom in $\mathrm{BF}_{4}^{-}$and $\mathrm{PF}_{6}{ }^{-}$) decreases in the order $\mathrm{Cl}^{-}>\mathrm{BF}_{4}^{-}>$ $\mathrm{PF}_{6}{ }^{-}$. According to the visualized pictures of the special distribution functions (SDFs) which show intuitively the three-dimensional probability distribution of the atoms of interest around a central ion, there are mainly three regions of the anion distributed 
around the caion in the first solvation shell.

$A b$ initio calculation of a series of EMIm-based salts reveals that the magnitude of the interaction energies of the ion pair follows the trend $\mathrm{CF}_{3} \mathrm{CO}_{2}^{-}>\mathrm{BF}_{4}^{-}>\mathrm{CF}_{3} \mathrm{SO}_{3}^{-}>$ $\left(\mathrm{CF}_{3} \mathrm{SO}_{2}\right)_{2} \mathrm{~N}^{-}>\mathrm{PF}_{6}^{-}$[114]. Most of the stable models for the ion pairs containing $\mathrm{EMIm}^{+}$ have an interaction via $\mathrm{C} 2$ hydrogen atom, whereas $\mathrm{BF}_{4}^{-}$in the model of $\mathrm{EDMIm}^{+}-\mathrm{BF}_{4}^{-}$ (EDMIm = 1-ethyl-2,3-dimethyimidazolium) ion pair is located at a position closer to the center of the ring. The small difference of the interaction energies between the cases for $\mathrm{EMIm}^{+}$and $\mathrm{EDMIm}^{+}$shows that the hydrogen bonding via C2 hydrogen atom of imidazolium ring is not essential for the attraction between the imidazolium ring and the anion. Comparison with experimental ion conductivities shows that the magnitude and directionality of the interaction energy between ions play a crucial role in determining the ionic dissociation/association dynamics in the ionic liquid (see 3.2).

Structure of EMIm(FH)2.3F was simulated by MD simulation [115]. As shown above and below, this system was studied by single-crystal X-ray diffraction at solid state (for EMImFHF, see 2.1), pulsed-gradient spin-echo NMR (see 3.2) and high energy X-ray diffraction (see 3.4). The MD simulation confirmed the short-range stacking of cations does exist but there is no evidence of the layer formation. [この話が Simonの論文にあ るのは知っていますが、我々の noncry の結果は水素結合があるということだった と思います。このまま Simonの言うとおりを引用するのはまずいのではないでし ようか][cation-anion 間の水素結合についてはnoncryで述べていないかと思うので すが][noncry ではなくsss のまちがいです。いずれにしても noncry で積極的に水 素結合がないと言っている箇所があるでしょうか].[水素結合に関する記述を取 り除きました] Furthermore, experimental X-ray diffraction spectra are quite well 
reproduced by this model. A similar imidazole-HF system was also investigated by $a b$ initio molecular orbital and density functional theory methods [116].

Some other computational studies combined with vibrational spectroscopy are summarized in 3.3 .

\subsection{NMR spectroscopy}

NMR spectroscopy is an effective method to study the ion-ion interactions in liquids including ionic liquids. In some early works on alkylimidazolium chloroaluminate salts, the ring hydrogen atoms, especially the one at the C2 position, shift upshield in the ${ }^{1} \mathrm{H}-\mathrm{NMR}$ spectra, as $\mathrm{Cl}^{-}$is replaced by $\mathrm{AlCl}_{4}^{-}$, which means the hydrogen atoms are more shielded by stronger hydrogen bonds to the anion $[4,117]$. On the other hand, two magnetically shielded cones above and below the imidazolium ring influences the chemical shift of the hydrogen atoms which penetrate into these cones and shifts it to the upfield [117]. These two phenomena are discussed by comparing chemical shifts in ${ }^{1} \mathrm{H}-\mathrm{NMR}$ spectra of acetone solutions of some EMIm salts at different concentrations [49]. For the salts containing more basic anions such as acetate anion, the chemical shift of the most acidic C2 hydrogen atom sharply increases with increase of the concentration. This is because the increase of concentration results in the stronger hydrogen bonds to the anion and the effect of the negatively charged atom in the anion is stronger than that of the neighboring imidazolium ring. In the cases of less basic anions such as $\mathrm{TFSI}^{-}$, the chemical shift decreases when the concentration increases, because the hydrogen bonds to the anion are weak and the effect of the neighboring imidazolium ring appears more strongly.

Diffusion coefficients of $\mathrm{EMIm}^{+}$measured by pulsed field gradient NMR for 
$\mathrm{EMImBF}_{4}$ indicates that structural change occurs at around $335 \mathrm{~K}$, which was supported by ${ }^{11} \mathrm{~B}$ quadrupolar relaxation rates $[118,119]$. This structural change was ascribed to the transformation of the diffusion particle from 'discrete ion-pair' to 'individual ion'. The mean radii for diffusing spheres in the two phases calculated by using the Stokes-Einstein equation are $2.79 \AA$ in the region of ion pair and $1.90 \AA$ in the region of individual ion. Similar observation was reported for $\mathrm{BMImBF}_{4}$ and $\mathrm{BMImPF}_{6}[120]$. Analysis of the ${ }^{13} \mathrm{C}$ dipole-dipole relaxation rates identified the formation of hydrogen bond $(\mathrm{C} 2-\mathrm{H} \cdots \mathrm{F})$ between $\mathrm{EMIm}^{+}$and $\mathrm{BF}_{4}^{-}$. According to the NMR measurements combined with the results of some physical properties and IR spectroscopy indicated that BMImBF 4 exists in an ion-pair (quasi-molecular) state below $279 \mathrm{~K}$ and BMImPF6 does between 273 and $353 \mathrm{~K}$, although the authors state that those ionic liquids form 'extended hydrogen bonding network' at higher temperature regions. In another report [121], the reorientational dynamics of $\mathrm{BMImPF}_{6}$ were studied by the measurement of ${ }^{13} \mathrm{C}$ spin-lattice relaxation rates and Nuclear Overhauser Effect (NOE) factors, where discontinuities in the relaxation curves were not observed for the neat $\mathrm{BMImPF}_{6}$. The presence of hydrogen bond between C2 hydrogen and F atom was confirmed by the dynamic method.

Cation-anion association in various ionic liquids was also studied by using pulsed-field gradient spin-echo NMR (PGSE-NMR) technique [122-125]. Molar conductivities of the ionic liquids calculated from the diffusion coefficients obtained by PGSE-NMR technique via Nernst-Einstein equation, $\Lambda_{\mathrm{NMR}}$, are larger than those obtained by $\mathrm{AC}$ impedance measurements, $\Lambda_{\mathrm{imp}}$. This phenomenon is explained by the ion-pairing between the cation and anion which reduces the charge carrier in the liquid and the ionic conductivity. For a series of BMIm-based ionic liquids, the $\Lambda_{\mathrm{imp}} / \Lambda_{\mathrm{NMR}}$ ratios follow the 


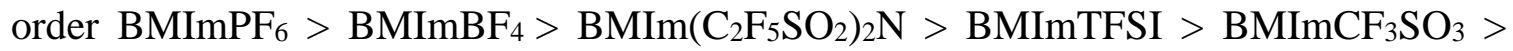
$\mathrm{BMImCF}_{3} \mathrm{CO}_{2}$ at $30{ }^{\circ} \mathrm{C}$. Since the cationic structure is fixed to $\mathrm{BMIm}^{+}$, the order of the ratio depends merely on the anionic character. On the other hand, the study for a series of 1-alky-3-methyllimidazolium TFSI salts shows that the $\Lambda_{\mathrm{imp}} / \Lambda_{\mathrm{NMR}}$ ratio decreases with increasing number of carbon atoms in the alkyl chain. For BMImPF6, the hydrodynamic volumes, $V_{\mathrm{D}}\left(=N_{\mathrm{A}} 4 \pi r^{3} / 3\right)$, observed for both the cation and anion by PGSE-NMR were much smaller than van der Waals' molar volumes, $V_{\mathrm{vdW}}$ [126], which indicates the smaller friction. There is relatively a lot of free space in $\mathrm{BMImPF}_{6}$, of which the molar volume $\left(V_{\mathrm{m}}=\mathrm{M} / \rho\right)$ calculated from the molar mass divided by the density is $0.205 \mathrm{~cm}^{3}$ $\mathrm{mol}^{-1}$ at $293 \mathrm{~K}$ much larger than the total van der Waals' molar volume $\left(0.122 \mathrm{~cm}^{3} \mathrm{~mol}^{-1}\right)$ of the cationic and anionic species. The free space could make a negative contribution to the effective friction and this negative effect is observed more remarkably for the cation than for the anion in view of $V_{\mathrm{D}} / V_{\mathrm{vdW}}$.

For a highly conductive ionic liquid, $\mathrm{RMIm}(\mathrm{FH})_{2.3 \mathrm{~F}}$ [28-32], the existence of cation-anion association was also suggested by PGSE-NMR. The aggregates of ordered ions, $\mathrm{A}(\mathrm{AX})_{\mathrm{m}}^{+}$and $(\mathrm{AX})_{\mathrm{n}} \mathrm{X}^{-}(\mathrm{A}=$ cation and $\mathrm{X}=$ anion $)$ are frequently changing their form and size by inserting and extracting some mono-ions at the surface [127]. Similar model was proposed for $(\mathrm{MBz})_{2} \mathrm{ImBF}_{4}, \mathrm{PF}_{6}$ and $\mathrm{BPh}_{4}$ by ${ }^{1} \mathrm{H}-\mathrm{NMR}$ measurements combined with conductivity and microcalorimetric measurements [39]. Recent ${ }^{1} \mathrm{H}$, ${ }^{19}$ F-HOESY (Heteronuclear Overhauser Effect Spectroscopy) studies on BMImBF 4 , BMImTFSI and $\mathrm{BMImPF}_{6}$ revealed that the anion does not occupy a specific position in this salt [128]. Moreover, in dichloromethane where the PGSE data show almost complete ion pairing, there are strong, non-selective NOE contacts between the cation and anion. This eliminates hydrogen bonding as the primary source of the interaction 
between the cation and anion, as this would lead to selectivity in the HOESY contacts. A structural motif to $\mathrm{BMImBF}_{4}$ in which the $\mathrm{BF}_{4}^{-}$straddles the imidazolium plane was proposed there. On the other hand, in the methanol solution, methanol solvates the ions and the cation-anion contacts is reduced.

Chemical shifts in ${ }^{1} \mathrm{H}-\mathrm{NMR}$ spectra of $\mathrm{BMImBF}_{4}$ and $\mathrm{BMImPF}_{6}$ were determined in various deuterated solvents [129]. The results show that the chemical shifts of ring hydrogen atoms of $\mathrm{BMImPF}_{6}$ are more sensitive to solvation than those of $\mathrm{BMImBF}_{4}$. The interaction of ring hydrogen atoms with the relatively small and basic $\mathrm{BF}_{4}^{-}$is more intimate than the interaction with the fairly large and less basic $\mathrm{PF}_{6}{ }^{-}$and for both the cases C2 hydrogen atom has a stronger interaction to the anion than the others. Chemical shifts of ${ }^{1} \mathrm{H}$ and ${ }^{13} \mathrm{C}$ NMR were also reported for a series of 1-alkyl-3-methylimidazolium salts containing $\mathrm{BF}_{4}^{-}$and $\mathrm{PF}_{6}{ }^{-}$in various solvents [130]. Cation-cation, cation-water and cation-anion interactions in the $\mathrm{BMImBF}_{4}-\mathrm{H}_{2} \mathrm{O}$ mixture were studied by NMR spectroscopy through NOEs [131]. The homonuclear NOE experiments indicated that the structure of pure $\mathrm{BMImBF}_{4}$ is changed towards a different organization with a lower degree of ring stacking (or other types of piling) or, in other words, the presence of water makes the imidazolium-imidazolium associations looser and that the methyl group shifts progressively towards the most hydrophobic part of the imidazolium ion, namely the $n$-butyl chain, as the water content raises. The results relating to water-cation protons shows that at very low water content the interaction is very specific and localized at ring hydrogen atoms. At higher water content, the interaction of water with the other hydrogen atoms in the side-chains increases and does not show any preference. The heteronuclear NOE experiments indicated the existence of tight ion pairs in the pure liquid even in the presence of small amounts of water and even in DMSO solution [132]. 


\subsection{Vibrational spectroscopy}

Vibrational spectroscopy has been employed to obtain information about inter-molecular interaction in ionic liquids. Conventionally, absorption bands assigned to C-H stretching modes of ring hydrogen atoms observed in the region between 3050 to $3100 \mathrm{~cm}^{-1}$ has been used as a criterion for a strong hydrogen bond [21,26,65,133-136].

Hydrogen bond structures of $\mathrm{BMImPF}_{6}$ as well as $\mathrm{DMImCH}_{3} \mathrm{SO}_{4}$ was studied by high pressure IR spectroscopy [135]. The pressure-dependent results indicate that the peak frequencies of the alkyl and imidazolium $\mathrm{C}-\mathrm{H}$ stretching bands have a non-monotonic pressure dependence. They blue-shift initially, then undergo no change, and blue-shift again upon increasing the pressure. This discontinuity in frequency shift is similar to the trend revealed for $\mathrm{DMImCH}_{3} \mathrm{SO}_{4} / \mathrm{D}_{2} \mathrm{O}$ mixture. The results indicate the existence of $\mathrm{C}-\mathrm{H} \cdots \mathrm{F}$ interactions between the $\mathrm{F}$ atoms of the $\mathrm{PF}_{6}{ }^{-}$and the ring $\mathrm{H}$ atoms of the cation. Additional hydrogen bond-like interactions were also observed between $\mathrm{PF}_{6}{ }^{-}$and the $\mathrm{H}$ atoms on the alkyl side-chains.

Recent reports on intermolecular interactions in ionic liquids using vibrational spectroscopy are usually combined with computational techniques. Structure of the ion pair in EMImBF 4 was described by ab initio and DFT calculation [136]. Only one final structure was obtained independently on the method. Unlike the chloride systems, where $\mathrm{Cl}^{-}$is found in the plane of the imidazolium ring of the cation, the $\mathrm{BF}_{4}^{-}$is positioned over the ring and has short contacts not only with the C2 hydrogen atom of the cation but also with a hydrogen atom of the methyl group (Fig. 7 copyright). The computations reveal that normal modes of the $\mathrm{EMIm}^{+}-\mathrm{BF}_{4}^{-}$ion pair rather closely resemble those of the isolated ions, except for antisymmetric B-F stretching vibrations of the anion, and 
out-of-plane and stretching vibrations of the C2-H moiety of the cation. The drastic increase of the $\mathrm{C} 2-\mathrm{H}$ out-of-plane wavenumber of $\mathrm{EMIm}^{+}$in the course of the ion-pair formation is strongly indicative of hydrogen bonding. However, the experimental IR spectra of neat and $\mathrm{CD}_{2} \mathrm{H}_{2}$ solution of $\mathrm{EMImBF}_{4}$ were almost identical. Probably, the cation and anion are held together mainly by powerful Coulombic attractions and hydrogen bond plays only a minor role. In another paper [137], DFT and RHF calculations reproduced Raman and IR spectra of $\mathrm{EMImBF}_{4}, \mathrm{MPImBF}_{4}$ and $\mathrm{BMImBF}_{4}$ using appropriate correction factors. Theoretical (DFT) alkyl side-chain conformational changes in the three ionic liquids have only a limited effect on the theoretical gas phase vibrations. The ion pair models suggest hydrogen bonds not only between the F atoms of the anion and the $\mathrm{C} 2$ hydrogen atom on the imidazolium ring but also between the $\mathrm{F}$ atoms of the anion and $\mathrm{H}$ atoms on the adjacent alkyl side chains in all polymorphic structures. Investigation of vibrational spectra of $\mathrm{EMImPF}_{6}, \mathrm{MPImPF}_{6}$ and $\mathrm{BMImPF}_{6}$ was made in the same manner [138]. Raman spectra of BMImPF6 and $\mathrm{HMImPF}_{6}$ were also assigned using ab initio calculation in another report [139]. The results indicated that almost equal amounts of two conformers observed in two polymorphs of BMImCl (one contains all anti and the other contains one gauche conformers for butyl chain) exist in $\mathrm{BMImPF}_{6}$ as already proposed for $\mathrm{BMImBF}_{4}$ in a previous study [66]. Similar results were obtained for the analogous two conformers in $\mathrm{HMImPF}_{6}$. The analysis of the HMImCl-HMImPF 6 binary system shows that neither the changes in hydrogen bonding to the ring hydrogen atoms nor the change in Coulombic environment has detectable effect upon the essentially 50:50 distribution of the two conformers. Conformational equilibrium of $\mathrm{EMIm}^{+}$in $\mathrm{EMImBF}_{4}, \mathrm{EMImPF}_{6}, \mathrm{EMImCF}_{3} \mathrm{SO}_{3}$ and $\mathrm{EMImTFSI} \mathrm{was}$ studied by the combination of Raman spectroscopy and theoretical calculations [140]. 
According to this report, the EMIm ${ }^{+}$exists as either a nonplanar $\left(\mathrm{C} 2-\mathrm{N} 1-\mathrm{C} 6-\mathrm{C} 7=110^{\circ}\right)$ or planar $\left(\mathrm{C} 2-\mathrm{N} 1-\mathrm{C} 6-\mathrm{C} 7=0^{\circ}\right)$ conformer in the ionic liquids and that the anionic environment hardly influences the equilibrium. On the other hand, conformational equilibrium of $\mathrm{TFSI}^{-}$in EMImTFSI investigated in the same way suggests that two conformers with two C-S-N-S dihedral angles of $\left(90.9^{\circ}, 90.9^{\circ}\right)$ and $\left(-81.2^{\circ}, 120.2^{\circ}\right)$ exist in the ionic liquid [141]. In another paper, dihedral distribution functions obtained by MD simulation for alkyl side-chains of various 1-alkyl-3-methylimidazolium salts combined with $\mathrm{BF}_{4}^{-}, \mathrm{PF}_{6}^{-}$and $\mathrm{TFSI}^{-}$[142] also indicated the existence of some conformers in the liquid states.

The molecular state of water in various alkylimidazolium-based ionic liquids was investigated by means of IR spectroscopy [143,144] and near infra-red spectroscopy [145].

\subsection{X-ray and neutron diffraction}

Since X-ray and neutron diffraction provide a direct picture of the averaged structure of liquid, they are powerful techniques to elucidate the liquid structure of ionic liquid. However, X-ray and neutron diffraction data on the structures of ionic liquids are limited so far probably due to their experimental difficulty. Structures of EMImFHF and RMIm(FH)2.3Fs were studied by High Energy X-ray diffraction [146,147]. X-ray diffraction patterns of liquid EMImFHF and EMIm(HF) ${ }_{2.3} \mathrm{~F}$ are similar to each other with a first sharp diffraction peak at $Q=1.85 \AA^{-1}$. This peak does not correspond to the ones in the calculated intra-molecular form factors for isolated $\mathrm{EMIm}^{+}$and $(\mathrm{HF})_{n} \mathrm{~F}^{-}(n=2,3)$ and the peak position coincides with the $\left(\begin{array}{lll}0 & 0 & 2\end{array}\right)$ diffraction peak in the powder X-ray pattern of solid EMImFHF corresponding to the layered structure (see 2.1 and Fig. 2), 
which suggests that such a layered structure may be partially preserved at the liquid state. All the other $\mathrm{RMIm}(\mathrm{FH})_{2.3 \mathrm{~F}}(\mathrm{R}=$ hydrogen, butyl and hexyl) ionic liquids showed similar diffraction pattern, but the value of the first sharp diffraction peak position shifts to lower diffraction angle with increasing the alkyl side-chain. This shift is considered to correspond to the increase in the inter-molecular distances in the ionic liquids.

Liquid structures of DMImPF6 and DMImTFSI were analyzed by neutron diffraction and the results were compared to the case for DMImCl [148-150]. The cation-cation contacts become larger as the size of the anion is increased, $\mathrm{Cl}^{-}<\mathrm{PF}_{6}{ }^{-}<\mathrm{TFSI}^{-}$. A similar trend is also seen for the cation-anion interactions. Although the anion shell is at a shorter distance from the central cation compared with the cation shells, the long-range alternating structure of cations and anions found in the $\mathrm{DMImCl}$ and $\mathrm{DMImPF}_{6}$ does not exist in DMImTFSI. The probability distributions of the cation and anion around the cation shows the anion density axial to the ring decreases $\mathrm{Cl}^{-}>\mathrm{PF}_{6}{ }^{-}>\mathrm{TFSI}^{-}$whereas the opposite is true for the facial anion density, $\mathrm{Cl}^{-}<\mathrm{PF}_{6}{ }^{-}<\mathrm{TFSI}^{-}$. DMIm ${ }^{+}$occupies the space where anion does not exist, i.e., the cations and the anions occupy mutually exclusive positions. This is more pronounced in the liquid structure of DMImTFSI than DMImPF6. The crystal structure and the liquid structure of DMImPF6 are very similar. For example, the large "holes" in the cation-cation distribution are found in both the liquid and solid states. Moreover, in both the states, short cation-cation contacts are found between methyl hydrogen atoms and the anion predominantly interacts with the ring and not the ring $\mathrm{H}$ atoms. On the other hand, comparison of the crystal structure and the liquid structure of DMImTFSI (see 2.2 and Fig. 6) indicates little correlation, for example, the TFSI $^{-}$adopts a trans-orientation predominantly in the liquid whereas a cis-orientation is found in the solid phase. The results for $\mathrm{DMImCl}$ and $\mathrm{DMImPF}_{6}$ were 
corroborated by MD simulations [151].

\subsection{Related studies}

Many computational studies have been made on ionic liquids containing non-alkylimidazolium cation or non-fluoroanion and on the mixtures of ionic liquids and solutes [22,152-175]. Various experimental (NMR spectroscopy [176-179], vibrational spectroscopy [160,173,174,180-182] and neutron diffraction [148,161,183]) studies are also employed for investigating structures of ionic liquids except those mentioned above. Results of another interesting method, electronspray ionization mass spectroscopy, has recently revealed that an ionic liquid can form aggregates and their size depends on the solvent used and the ionic liquid concentration [184,185].

\section{Summary}

This review summarizes studies on structures of alkylimidazolium-based salts containing fluoroanions from the viewpoint of crystallographic, computational, spectroscopic and diffraction techniques. Various models have been proposed to describe the structures of ionic liquids, but none of them seems to be perfect yet. Some results clearly contradict with each other, especially for ion-ion interaction and hydrogen bonding at liquid state, even if the system examined is exactly the same. Although structures of neat ionic liquids are mainly treated here, the ionic liquid-solvent or ionic liquid-ionic liquid mixtures make the discussion more difficult. 


\section{Figure captions}

Fig. 1 Structure of alkylimidazolium cation.

Fig. 2 Layered structure of EMImFHF viewed from the direction perpendicular to the $b$-axis [27].

Fig. 3 Molecular packing in the structures of (a) EMImNbF 6 and (b) EMImAsF 6 [33].

Fig. 4 View of the crystal structure of (a) $(\mathrm{MBz})_{2} \operatorname{ImBF}_{4}$ along the crystallographic $b$-axis and (b) (MBz) ${ }_{2} \operatorname{ImPF} 6$ along the crystallographic c-axis [39]. Hydrogen atoms are omitted for clarity; $\mathrm{BF}_{4}^{-}$and $\mathrm{PF}_{6}{ }^{-}$are shown as tetrahedra and octahedra, respectively.

Fig. 5 Overall structure of $\mathrm{C}_{12} \mathrm{MImPF}_{6}$ showing the interdigitation and the tilted alkyl chains [43].

Fig. 6 Cation $\cdots$ anion hydrogen bonding in DMImTFSI, showing the three in-plane cations surrounding each anion resulting in the cis-anion conformation with all the $\mathrm{CF}_{3}$ groups in each hydrogen-bonded sheet projecting from the same side of the layer [55].

Fig. 7 B3LYP/6-31+G*-Calculated molecular structure of EMImBF4 [136].

Fig. 8 Center of mass radial distribution functions for the cation and anion obtained from the three force fields at $298 \mathrm{~K}$ [107]. AA: all atom force-field [105], UA1: united atom force-field 1 [102], UA2 united atom force-field 2 [107]. 
Table 1 Structural parameters and melting points of alkylimidazolium salts containing fluoroanions

\begin{tabular}{|c|c|c|c|c|c|c|c|}
\hline \multirow[t]{2}{*}{ Salt $^{a}$} & \multicolumn{5}{|c|}{ Cell parameters ${ }^{b}$} & \multirow[t]{2}{*}{$T_{m} / \mathrm{K}^{b}$} & \multirow[t]{2}{*}{ Ref. } \\
\hline & S.G. & $V / \AA^{3}$ & $\mathrm{Z}$ & $D_{c} / \mathrm{gcm}^{-3}$ & $T / \mathrm{K}$ & & \\
\hline $\mathrm{DMIm}^{+} \mathrm{PF}_{6}^{-}$ & Pbca & 1894 & 8 & 1.698 & 173 & - & [24] \\
\hline $\mathrm{DMIm}^{+} \mathrm{PF}_{6}^{-} \cdot 0.5 \mathrm{C}_{6} \mathrm{H}_{6}$ & $P 2_{1} / c$ & 1176.2 & 4 & 1.588 & 150 & - & [24] \\
\hline $\mathrm{DMIm}^{+} \mathrm{TFSI}^{-}$ & $P-1$ & 1417.0 & 4 & 1.769 & 173 & 295 & [55] \\
\hline $\mathrm{EMIm}^{+} \mathrm{FHF}^{-}$ & $P 2_{1} / m$ & 395.09 & 2 & 1.262 & 298 & 324 & [27] \\
\hline \multirow[t]{2}{*}{$\mathrm{EMIm}^{+} \mathrm{BF}_{4}^{-}$} & $P 2_{1} / C$ & 906.8 & 4 & 1.450 & 100 & 288 & [33] \\
\hline & $P 2_{1} / n$ & 929.86 & 4 & 1.41 & 173 & 271.7 & [34] \\
\hline $\mathrm{EMIm}^{+} \mathrm{PF}_{6}^{-}$ & $P 2_{1} / c$ & 1092.02 & 4 & 1.558 & 283-303 & 333 & [26] \\
\hline $\mathrm{EMIm}^{+} \mathrm{AsF}_{6}^{-}$ & $P 2_{1} / c$ & 1123.04 & 4 & 1.775 & 298 & 326 & [21] \\
\hline EMIm $^{+} \mathrm{SbF}_{6}^{-}$ & $P 2_{1} / c$ & 1138.8 & 4 & 2.024 & 200 & 283 & [21] \\
\hline $\mathrm{EMIm}^{+} \mathrm{NbF}_{6}^{-}$ & $P 2_{1} 2_{1} 2_{1}$ & 1124 & 4 & 1.880 & 200 & 272 & [33] \\
\hline $\mathrm{EMIm}^{+} \mathrm{TaF}_{6}{ }^{-}$ & $P 2_{1} 2_{1} 2_{1}$ & 1124.9 & 4 & 2.398 & 200 & 275 & [33] \\
\hline $\mathrm{EMIm}^{+} \mathrm{Li}^{+}{ }_{2}\left(\mathrm{TFSI}^{-}\right)_{3}$ & $P 2_{1} / c$ & 3561.2 & 4 & 1.801 & 298 & - & [59] \\
\hline EMImTFSI $\cdot \mathrm{C}_{6} \mathrm{H}_{6}$ & $P 2_{1} / n$ & 1989.6 & 4 & 1.567 & 110 & 288 & [57] \\
\hline $\mathrm{BMIm}^{+} \mathrm{F}^{-} \cdot \mathrm{H}_{2} \mathrm{O}$ & $P 2_{1} 2_{1} 2_{1}$ & 995.7 & 4 & 1.176 & 173 & - & [23] \\
\hline \multirow[t]{2}{*}{$\mathrm{BMIm}^{+} \mathrm{PF}_{6}^{-}$} & $P-1$ & 610.2 & 2 & 1.55 & 180 & 274.9 & [34] \\
\hline & $P-1$ & 604.96 & 2 & 1.560 & 173 & 284 & [36] \\
\hline $\mathrm{BMIm}^{+} \mathrm{OSO}_{2} \mathrm{CF}_{3}^{-}$ & $P 2_{1} / n$ & 2883.2 & 8 & 1.33 & 200 & 279.7 & [34] \\
\hline 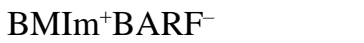 & $P 2_{1} / n$ & 8625.3 & 8 & 1.544 & 200 & 375-377 & [61] \\
\hline $\mathrm{PNMIm}^{+} \mathrm{PF}_{6}^{-}$ & $P-1$ & 597.1 & 2 & 1.642 & 140 & 348 & [41] \\
\hline $\mathrm{PNDMIm}^{+} \mathrm{PF}_{6}^{-}$ & $P-1$ & 650.7 & 2 & 1.578 & 140 & 358 & [41] \\
\hline $\mathrm{BDMIm}^{+} \mathrm{BF}_{4}^{-}$ & $P 2_{1} / c$ & 2491.79 & 8 & 1.307 & 213 & 312.8 & [37] \\
\hline $\mathrm{BDMIm}^{+} \mathrm{PF}_{6}^{-}$ & Cc & 1310.4 & 4 & 1.512 & 213 & 313.0 & [37] \\
\hline $\mathrm{BDMIm}^{+} \mathrm{SbF}_{6}^{-}$ & $P 2_{1} / n$ & 1457.27 & 4 & 1.773 & 293 & 317.5 & [37] \\
\hline TEIm $^{+}$TFSI $^{-}$ & $P 2_{1} / n$ & 1803 & 4 & 1.597 & 173 & 330 & [55] \\
\hline $\mathrm{DBIm}^{+} \mathrm{OSO}_{2} \mathrm{CF}_{3}^{-}$ & $\mathrm{Pbca}$ & 3240.9 & 8 & 1.345 & 150 & - & [60] \\
\hline $\mathrm{Me}_{3} \mathrm{NBH}_{2} \mathrm{MIm}^{+} \mathrm{TFSI}^{-}$ & $P-1$ & 922.0 & 2 & 1.564 & 173 & 333.2 & [54] \\
\hline EtOC(O)CEtIm ${ }^{+}$TFSI $^{-}$ & $P 2_{1} / c$ & 1871.91 & 4 & 1.644 & 223 & 318 & [58] \\
\hline EMBzIm $^{+} \mathrm{TFSI}^{-}$ & $P 2_{1} / n$ & 2061 & 4 & 1.552 & 295 & 323 & [53] \\
\hline$\left.(\mathrm{DMImMCp})_{2} \mathrm{Fe}^{2+} \mathrm{PF}_{6}^{-}\right)_{2}$ & $P-1$ & 641.6 & 1 & 1.797 & 84 & dec. $^{c}$ & [42] \\
\hline DisoPDMIm $^{+} \mathrm{BF}_{4}^{-}$ & $P 4_{3} 2_{1} 2$ & 1416.9 & 4 & 1.257 & 293 & 410 & [186] \\
\hline$(\mathrm{MBz})_{2} \mathrm{Im}^{+} \mathrm{BF}_{4}^{-}$ & $P 2_{1} 2_{1} 2_{1}$ & 1801.85 & 4 & 1.343 & 150 & 383 & [39] \\
\hline$(\mathrm{MBz})_{2} \mathrm{Im}^{+} \mathrm{PF}_{6}^{-}$ & $P 2_{1} 2_{1} 2_{1}$ & 1916.40 & 4 & 1.464 & 100 & 381 & [39] \\
\hline $\mathrm{C}_{12} \mathrm{MIm}^{+} \mathrm{PF}_{6}^{-}$ & $P 2_{1} / a$ & 2000.7 & 4 & 1.32 & 123 & 333 & [43] \\
\hline $\mathrm{C}_{14} \mathrm{MIm}^{+} \mathrm{PF}_{6}^{-}$ & $P 2_{1} / a$ & 2204.84 & 4 & 1.279 & 175 & $348^{d}$ & [44] \\
\hline
\end{tabular}

${ }^{a}$ DMIm: 1,3-dimethylimidazolium, EMIm: 1-ethyl-3-methylimidazolium, BMIm:

1-butyl-3-methylimidazolium, PNMIm: 1-methyl-3-propylnitrileimidazolium, PNDMIm:

1,2-dimethyl-3-propylnitrileimidazolium, BDMIm: 1-butyl-2,3-dimethylimidazolium, TEMIm:

1,2,3-triethylimidazolium, DBIm: 1,3-di-tert-butylimidazolium, $\mathrm{Me}_{3} \mathrm{NBH}_{2} \mathrm{MIm}$ :

( $N$-methylimidazole)(trimethylamine)boronium, EtOC(O)CEtIm:

1-(1-(R)-Ethoxycarbonyl-ethyl)-3-methyl-imidazolium, EMBzIm:

1-ethyl-2-methy-3-benzyl-imidazolium, (DMImMCp) ${ }_{2} \mathrm{Fe}$ :

1,1'-bis $\{[1$-(2,3-dimethyl)imidazolium]methyl $\}$ ferrocene, DisoPDMIm:

1,3-di-iso-propyl-4,5-dimethyl-imidazolium, (MBz) 2 Im: 1,3-di-R-(+)-methylbenzyl-imidazolium, $\mathrm{C}_{12} \mathrm{MIm}$ : 1-dodecyl-3-methylimidazolium, $\mathrm{C}_{14} \mathrm{MIm}$ : 1-methyl-3-tetradecylimidazolium, TFSI:

bis(trifluoromethylsulfonyl)amide, BARF: tetrakis(3,5-bis(trifluoromethyl)phenyl)borate. ${ }^{b}$ S.G.: Space group, $V$ : Cell volume, $Z$ : Number of formula units in the unit cell, $D_{c}$ : Density calculated from cell parameters, $T$ : Data collection temperature, $T_{m}$ : Melting point. ${ }^{c}$ dec.: decomposition without melting, ${ }^{d}$ Crystalline to smectic phase transition. 
Table 2 Computational and experimental studies on ion-ion interactions and liquid structures of alkylimidazolium-based room temperature ionic liquids containing fluoroanions

\begin{tabular}{|c|c|c|}
\hline Method & Salt $^{a}$ & Reference \\
\hline \multirow[t]{20}{*}{ Calculation } & $\mathrm{DMIm}^{+} \mathrm{BF}_{4}^{-}$ & [111] \\
\hline & $\mathrm{DMIm}^{+} \mathrm{PF}_{6}^{-}$ & {$[103,110,111,151]$} \\
\hline & $\mathrm{EMIm}^{+}(\mathrm{HF})_{2.3} \mathrm{~F}^{-}$ & [115] \\
\hline & $\mathrm{EMIm}^{+} \mathrm{BF}_{4}^{-}$ & {$[101,110,111,114,142]$} \\
\hline & $\mathrm{EMIm}^{+} \mathrm{PF}_{6}^{-}$ & {$[111,114,142]$} \\
\hline & $\mathrm{EMIm}^{+} \mathrm{CF}_{3} \mathrm{CO}_{2}^{-}$ & [114] \\
\hline & $\mathrm{EMIm}^{+} \mathrm{CF}_{3} \mathrm{SO}_{3}^{-}$ & {$[114,142]$} \\
\hline & $\mathrm{EMIm}^{+} \mathrm{TFSI}^{-}$ & {$[114,142]$} \\
\hline & $\mathrm{EDMIm}^{+} \mathrm{BF}_{4}^{-}$ & [114] \\
\hline & $\mathrm{MPIm}^{+} \mathrm{BF}_{4}^{-}$ & [111] \\
\hline & $\mathrm{MPIm}^{+} \mathrm{PF}_{6}^{-}$ & {$[111,142]$} \\
\hline & $\mathrm{BMIm}^{+} \mathrm{BF}_{4}^{-}$ & {$[110,111,142]$} \\
\hline & $\mathrm{BMIm}^{+} \mathrm{PF}_{6}^{-}$ & {$[102,104-113,142,151]$} \\
\hline & $\mathrm{BMIm}^{+} \mathrm{CF}_{3} \mathrm{CO}_{2}^{-}$ & [109] \\
\hline & $\mathrm{BMIm}^{+} \mathrm{C}_{3} \mathrm{~F}_{7} \mathrm{CO}_{2}^{-}$ & [110] \\
\hline & $\mathrm{BMIm}^{+} \mathrm{CF}_{3} \mathrm{SO}_{3}^{-}$ & [111] \\
\hline & $\mathrm{BMIm}^{+} \mathrm{C}_{4} \mathrm{~F}_{9} \mathrm{SO}_{3}^{-}$ & [112] \\
\hline & $\mathrm{BMIm}^{+} \mathrm{TFSI}^{-}$ & [142] \\
\hline & $\mathrm{HMIm}^{+} \mathrm{PF}_{6}^{-}$ & [142] \\
\hline & $\mathrm{C}_{12} \mathrm{MIm}^{+} \mathrm{PF}_{6}^{-}$ & [142] \\
\hline \multirow[t]{22}{*}{$\overline{\mathrm{NMR}}$} & $\mathrm{DMIm}^{+}(\mathrm{HF})_{2.3} \mathrm{~F}^{-}$ & [127] \\
\hline & $\mathrm{DMIm}^{+} \mathrm{TFSI}^{-}$ & [124] \\
\hline & $\mathrm{EMIm}^{+}(\mathrm{HF})_{2.3} \mathrm{~F}^{-}$ & [127] \\
\hline & $\mathrm{EMIm}^{+} \mathrm{BF}_{4}^{-}$ & {$[118,119,122,130]$} \\
\hline & $\mathrm{EMIm}^{+} \mathrm{PF}_{6}^{-}$ & [130] \\
\hline & $\mathrm{EMIm}^{+} \mathrm{TFSI}^{-}$ & {$[122,124]$} \\
\hline & $\operatorname{MPIm}^{+}(\mathrm{HF})_{2.3} \mathrm{~F}^{-}$ & [127] \\
\hline & $\mathrm{BMIm}^{+}(\mathrm{HF})_{2.3} \mathrm{~F}^{-}$ & {$[127]$} \\
\hline & $\mathrm{BMIm}^{+} \mathrm{BF}_{4}^{-}$ & {$[120,123,128-131]$} \\
\hline & $\mathrm{BMIm}^{+} \mathrm{PF}_{6}^{-}$ & {$[120,121,123,126,128-130]$} \\
\hline & $\mathrm{BMIm}^{+} \mathrm{CF}_{3} \mathrm{CO}_{2}^{-}$ & [123] \\
\hline & $\mathrm{BMIm}^{+} \mathrm{CF}_{3} \mathrm{SO}_{3}^{-}$ & {$[123]$} \\
\hline & $\mathrm{BMIm}^{+} \mathrm{TFSI}^{-}$ & {$[123,124,128]$} \\
\hline & $\mathrm{BMIm}^{+}\left(\mathrm{C}_{2} \mathrm{~F}_{5} \mathrm{SO}_{2}\right)_{2} \mathrm{~N}^{-}$ & [123] \\
\hline & $\mathrm{MPeIm}^{+}(\mathrm{HF})_{2.3} \mathrm{~F}^{-}$ & [127] \\
\hline & $\operatorname{HMIm}^{+}(\mathrm{HF})_{2.3} \mathrm{~F}^{-}$ & [127] \\
\hline & $\mathrm{HMIm}^{+} \mathrm{TFSI}^{-}$ & [124] \\
\hline & $\mathrm{MOIm}^{+} \mathrm{BF}_{4}^{-}$ & [130] \\
\hline & $\mathrm{MOIm}^{+} \mathrm{PF}_{4}^{-}$ & [130] \\
\hline & $\mathrm{MOIm}^{+} \mathrm{TFSI}^{-}$ & [124] \\
\hline & $(\mathrm{MBz})_{2} \mathrm{Im}^{+} \mathrm{BF}_{4}^{-}$ & [39] \\
\hline & $(\mathrm{MBz})_{2} \mathrm{Im}^{+} \mathrm{PF}_{6}^{-}$ & [39] \\
\hline \multirow[t]{9}{*}{$\overline{\text { IR·Raman }}$} & $\mathrm{EMImBF}_{4}$ & {$[136,137,140]$} \\
\hline & $\mathrm{EMImPF}_{6}$ & {$[138,140]$} \\
\hline & $\mathrm{EMImCF}_{3} \mathrm{SO}_{3}$ & [140] \\
\hline & EMImTFSI & {$[140,141]$} \\
\hline & $\mathrm{MPImBF}_{4}$ & [137] \\
\hline & $\mathrm{MPImPF}_{6}$ & [138] \\
\hline & $\mathrm{BMImBF}_{4}$ & {$[66,135,137]$} \\
\hline & $\mathrm{BMImPF}_{6}$ & {$[138,139]$} \\
\hline & $\mathrm{HMImPF}_{6}$ & [139] \\
\hline
\end{tabular}




\begin{tabular}{llllll}
\hline X-ray & $\mathrm{EMImFHF}_{\text {diffraction }}$ & {$[146]$} & & & \\
& $\mathrm{MIm}^{+}(\mathrm{HF})_{2.3} \mathrm{~F}^{-}$ & {$[147]$} & & & \\
& $\mathrm{EMIm}^{+}(\mathrm{HF})_{2.3} \mathrm{~F}^{-}$ & {$[146,147]$} & & \\
& $\mathrm{BMIm}^{+}(\mathrm{HF})_{2.3} \mathrm{~F}^{-}$ & {$[147]$} & & & \\
& $\mathrm{HMIm}^{+}(\mathrm{HF})_{2.3} \mathrm{~F}^{-}$ & {$[147]$} & & & \\
\hline $\begin{array}{l}\text { Neutron } \\
\text { diffraction }\end{array} \mathrm{DMIm}^{+} \mathrm{PF}_{6}^{-}$ & {$[149]$} & & & \\
\hline aMIm ${ }^{-} \mathrm{TFSI}^{-}$ & {$[150]$} & MIm: & 1-methylimidazolium, MPIm: & 1-methyl-3-propylimidazolium, & MPeIm: \\
1-methyl-3-pentylimidazolium, & HMIm: & 1-hexyl-3-methylimidazolium, & MOIm: \\
1-methyl-3-octylimidazolium, & & & & \\
\hline
\end{tabular}




\section{References}

[1] P. Walden, Bull. Acad. Imper. Sci. (St. Petersburg) (1914) 405-422.

[2] C.M. Gordon, Appl. Catal. A 222 (2001) 101-117.

[3] J.S. Wilkes, J.A. Levisky, R.A. Wilson, C.L. Hussey, Inorg. Chem. 21 (1982) 1263-1264.

[4] A.A. Fanning Jr., D.A. Floreani, L.A. King, S.S. Landers, B.J. Piersma, D.J. Stech, R.L. Vaughn, J.S. Wilkes, J.L. Williams, J. Phys. Chem. 88 (1984) 2609-2614.

[5] A.A. Fanning Jr., D.A. Floreani, L.A. King, S.S. Landers, B.J. Piersma, D.J. Stech, R.L. Vaughn, J.S. Wilkes, J.L. Williams, J. Phys. Chem. 88 (1984) 2614-2621.

[6] R. Hagiwara, Y. Ito, J. Fluorine Chem. 105 (2000) 221-227.

[7] R. Hagiwara, Electrochemistry 70 (2002) 130-136.

[8] H. Xue, R. Verma, J.M. Shreeve, J. Fluorine Chem. 127 (2006) 159-176

[9] T. Welton, Chem. Rev. 99 (1999) 2071-2083.

[10] K.R. Seddon, J. Chem. Technol. Biotechnol. 68 (1997) 351-356.

[11] P. Wasserscheid, W. Kein, Angew. Chem. Int. Ed. 39 (2000) 3772-3789.

[12] J. Dupont, R.F. de Souza, P.A.Z. Suarez, Chem. Rev. 102 (2002) 3667-3692.

[13] H. Olivier-Bourbigou, L. Magna, J. Mol. Catal. A 182-183 (2002) 419-437.

[14] J.D. Holbrey, K.R. Seddon, Clean Prod. Proc. 1 (1999) 223-236.

[15] R. Sheldon, Chem. Commun. 2001, 2399-2407.

[16] H. Ohno, ed., "Electrochemical Aspects of Ionic Liquids", John Wiley and Sons, Inc., New Jersey, 2005.

[17] K. Ui, M. Ueda, R. Hagiwara, M. Mizuhata, Yoyuen oyobi Koon Kagaku 47(3) (2004) 114-123.

[18] D. Inman, D. Lovering, eds., “Ionic Liquid”, Plenum Press, New York, 1981. 
[19] J.S. Wilkes, M.J. Zaworotko, J. Chem. Soc., Chem. Commun. 1992, 965-967.

[20] K. Matsumoto, R. Hagiwara, Y. Ito, J. Fluorine Chem. 115 (2002) 133-135.

[21] K. Matsumoto, R. Hagiwara, R. Yoshida, Y. Ito, Z. Mazej, P. Benkič, B. Žemva, O.

Tamada, H. Yoshino, S. Matsubara, Dalton Trans. 2004, 144-149.

[22] E.A. Turner, C.C. Pye, R.D. Singer, J. Phys. Chem. A 107 (2003) 2277-2288.

[23] R.P. Swatloski, J.D. Holbrey, R.D. Rogers, Green Chem. 5 (2003) 361-363.

[24] J.D. Holbrey, W.M. Reichert, M. Nieuwenhuyzen, O. Sheppard, C. Hardacre, R.D. Rogers, Chem. Commun. 2003, 476-477.

[25] M. Deetlefs, C. Hardacre, M. Nieuwenhuyzen, O. Sheppard, A.K. Soper, J. Phys. Chem. B 109 (2005) 1593-1598.

[26] J. Fuller, R.T. Carlin, H.C. De Long, D. Haworth, J. Chem. Soc., Chem. Commun., 1994, 299-300.

[27] K. Matsumoto, T. Tsuda, R. Hagiwara, Y. Ito, O. Tamada, Solid State Sci. 4 (2002) 23-26.

[28] R. Hagiwara, T. Hirashige, T. Tsuda, Y. Ito, J. Fluorine Chem. 99 (1999) 1-3.

[29] R. Hagiwara, T. Hirashige, T. Tsuda, Y. Ito, J. Electrochem. Soc. 149 (2002) D1-D6.

[30] R. Hagiwara, K. Matsumoto, Y. Nakamori, T. Tsuda, Y. Ito, H. Matsumoto, K. Momota, J. Electrochem. Soc. 150 (2003) D195-D199.

[31] R. Hagiwara, Y. Nakamori, K. Matsumoto, Y. Ito, J. Phys. Chem. B 109 (2005) 5445-5449.

[32] K. Matsumoto, R. Hagiwara, Y. Ito, S. Kohara, K. Suzuya, Nucl. Instrum. Meth. B. 199 (2003) 29-33.

[33] K. Matsumoto, R. Hagiwara, Z. Mazej, P. Benkič, B. Žemva, Solid State Sci. (2006) 
in press.

[34] A.R. Choudhury, N. Winterton, A. Steiner, A.I. Cooper, K.A. Johnson, J. Am. Chem. Soc. 127 (2005) 16792-16793.

[35] M. Hasan, I.V. Kozhevnikov, M.R.H. Siddiqui, C. Femoni, A. Steiner, N. Winterton, Inorg. Chem. 40 (2001) 795-800.

[36] S.M. Dibrov, J.K. Kochi, Acta Cryst. C62 (2006) o19-o21.

[37] P. Kölle, R. Dronskowski, Eur. J. Inorg. Chem. 2004, 2313-2320.

[38] P. Kölle, R. Dronskowski, Inorg. Chem. 43 (2004) 2803-2809.

[39] C.S. Consorti, P.A.Z. Suarez, R.F. de Souza, R.A. Burrow, D.H. Farrar, A.J. Lough,

W. Loh, L.H.M. da Silva, J. Dupont, J. Phys. Chem. B 109 (2005) 4341-4349.

[40] J. Dupont, P.A.Z. Suarez, R.F. de Souza, R.A. Burrow, J.P. Kintzinger, Chem. Eur. J. 6 (2000) 2377-2381.

[41] D. Zhao, Z. Fei, R. Scopelliti, P.J. Dyson, Inorg. Chem. 43 (2004) 2197-2205.

[42] Y. Gao, B. Twamley, J.M. Shreeve, Inorg. Chem. 43 (2004) 3406-3412.

[43] C.M. Gordon, J.D. Holbrey, A.R. Kennedya, K.R. Seddon, J. Mater. Chem. 8 (1998) 2627-2636.

[44] J. De Roche, C.M. Gordon, C.T. Imrie, M.D. Ingram, A.R. Kennedy, F. Lo Celso, A. Triolo, Chem. Mater. 15 (2003) 3089-3097.

[45] S. Kunsági-Máté, B. Lemli, G. Nagy, L. Kollár, J. Phys. Chem. B 108 (2004) 9246-9250.

[46] K.R. Seddon, C.J. Bowlas, D.W. Bruce, Chem. Commun. 1996, 1625-1626.

[47] K. Binnemans, Chem. Rev 105 (2005) 4148-4204.

[48] J.L. Nowinski, P. Lightfoot, P.G. Bruce, J. Mater. Chem. 4 (1994) 1579-1580.

[49] P. Bonhôte, A.-P. Dias, M. Armand, N. Papageorgiou, K. Kalyanasundaram, M. 
Grätzel, Inorg. Chem. 35 (1996) 1168-1178.

[50] R.P. Singh, S. Manandhar, J.M. Shreeve, Tetrahedron Lett. 43 (2002) 9497-9499.

[51] C.M. Jin, J.M. Shreeve, Inorg. Chem. 43 (2004) 7532-7538.

[52] D.R. MacFarlane, P. Meakin, J. Sun, N. Amini, M. Forsyth, J. Phys. Chem. B 103 (1999) 4164-4170.

[53] J.J. Golding, D.R. MacFarlane, L. Spiccia, M. Forsyth, B.W. Skeltonc, A.H. Whitec, Chem. Commun. (1998) 1593-1594.

[54] P.A. Fox, S.T. Griffin, W.M. Reichert, E.A. Salter, A.B. Smith, M.D. Tickell, B.F. Wicker, E.A. Cioffi, J.H. Davis, Jr., R.D. Rogers, A. Wierzbicki, Chem Commun 2005, $3679-3681$.

[55] J.D. Holbrey, W.M. Reichert, R.D. Rogers, Dalton Trans. 2004, 2267-2271.

[56] L.X. Xue, C.W. Padgett, D.D. Desmarteau, W.T. Pennington, Solid State Sci. 4 (2002) 1535-1545.

[57] J. Łachwa, I. Bento, M.T. Duarte, J.N.C. Lopes, L.P.N. Rebelo, Chem Commun. 2006, 2445-2447.

[58] J.J. Jodry, K. Mikami, Tetrahedron Lett. 45 (2004) 4429-4431

[59] K. Matsumoto, R. Hagiwara, O. Tamada, Solid State Sci. (2006) in press.

[60] E. Rijnberg, B. Richter, K.-H. Thiele, J. Boersma, N. Veldman, A.L. Spek, G. van Koten, Inorg. Chem. 37 (1998) 56-63.

[61] J. Finden, G. Beck, A. Lantz, R. Walsh, M.J. Zaworotko, R. D. Singer, J. Chem. Crystallogr. 33 (2003) 287-295.

[62] A.J. Arduengo, H.V.R. Dias, R.L. Harlow, M. Kline, J. Am. Chem. Soc. 114 (1992) $5530-5534$.

[63] C.J. Dymek Jr., D.A. Grossie, A.V. Fratini, W.W. Adams, J. Mol. Struc. 213(1989) 
25-34.

[64] A.K. Abudul-Sada, A.M. Greenway, P.B. Hitchcock, T.J. Mohammed, K.R. Seddon, J.A. Zora, J. Chem. Soc., Chem. Commun. 1986, 1753-1754.

[65] A. Elaiwi, P.B. Hitchcock, K.R. Seddon, N. Srinivasan, Y.-M Tan, T. Welton, J.A. Zora, J. Chem. Soc., Dalton Trans. 1995, 3467-3472.

[66] R. Ozawa, S. Hayashi, S. Saha, A. Kobayashi, H. Hamaguchi, Chem. Lett. 32 (2003) 948-949.

[67] S. Hayashi, R. Ozawa, H. Hamaguchi, Chem. Lett. 32 (2003) 498-499.

[68] S. Saha, S. Hayashi, A. Kobayashi, H. Hamaguchi, Chem. Lett. 32 (2003) 740-741.

[69] J.D. Holbrey, W.M. Reichert, M. Nieuwenhuyzen, S. Johnston, K.R. Seddon, R.D. Roger, Chem. Commun. 2003,1636-1637.

[70] J.L. Anderson, R. Ding, A. Ellern, D.W. Armstrong, J. Am. Chem. Soc. 127 (2005) 593-604.

[71] Z. Fei, D. Zhao, T.J. Geldbach, R. Scopelliti, P.J. Dyson, Chem. Eur. J. 10 (2004) 4886-4893.

[72] J.A. Boon, R.T. Carlin, A.M. Elias, J.S. Wilkes, J. Chem. Cryst. 25 (1995) 57-62

[73] P.B. Hitchcock, K.R. Seddon, T. Welton, J. Chem. Soc., Dalton Trans. 1993, 2639-2643.

[74] M.F. Ortwerth, M.J. Wyzlic, R.G. Baughman, Acta Cryst. C54 (1998) 1594-1596.

[75] N. Kuhn, M. Göhner, M. Steimann, C. Nachtigal, Z. Kristallogr. NCS 214 (1999) 565-566.

[76] N. Kuhn, R. Fawzi, H. Kotowski, M. Steimann, Z. Kristallogr. 213 (1998) 435-436.

[77] M. Hasan, I.V. Kozhevnikov, M.R.H. Siddiqui, A. Steiner, N. Winterton, Inorg. Chem. 38 (1999) 5637-5641. 
[78] K. Matsumoto, T. Tsuda, T. Nohira, R. Hagiwara, Y. Ito, O. Tamada, Acta Cryst., C58 (2002) m186-m187.

[79] H.J. Sun, K. Harms J. Sundermeyer, Z. Kristallogr. 220 (2005) 42-44.

[80] D.J. Williams, W.T. Pennington, D. VanDerveer, J.T. Anderton, K.M. White, J. Chem. Cryst. 33 (2003) 465-472.

[81] P.B. Hitchcock, R.J. Lewis, T. Welton, Polyhedron 12 (1993) 2039-2044

[82] P.B. Hitchcock, T.J. Mohammed, K.R. Seddon, J.A. Zora, C.L. Hussey, E.H. Ward, Inorg. Chim. Acta 113 (1986) L25-L26.

[83] D. Appleby, P.B. Hitchcock, K.R. Seddon, J.E. Turp, J.A. Zora, C.L. Hussey, J.R. Sanders, T.A. Ryan, J. Chem. Soc., Dalton Trans. 1990, 1879-1887.

[84] Y. Yoshida, K. Muroi, A. Otsuka, G. Saito, M. Takahashi, T. Yoko, Inorg. Chem., 43 (2004) 1458-1462.

[85] J.D. Holbrey, W.M. Reichert, R.P. Swatloski, G.A. Broker, W.R. Pitner, K.R. Seddon, R.D. Rogers, Green Chem. 4 (2002) 407-413.

[86] A.S. Larsen, J.D. Holbrey, F.S. Tham, C.A. Reed, J. Am. Chem. Soc. 122 (2000) 7264-7272.

[87] N. Kuhn, H. Bohnen, G. Henkel, Z. Kristallogr. 211 (1996) 57-57.

[88] A.E. Bradley, C. Hardacre, M. Nieuwenhuyzen, W.R. Pitner, D. Sanders, K.R. Seddon, R.C. Thied, Inorg. Chem. 43 (2004) 2503-2514.

[89] K. Matsumoto R. Hagiwara, Y. Ito, Electrochem. Solid State Lett. 7 (2004) E41-E44.

[90] H. Matsumoto, H. Kageyama, Y. Miyazaki, Chem. Commun. 2002, 1726-1727.

[91] H. Matsumoto, Y. Miyazaki, Chem. Lett. 2000, 922-923.

[92] J. Golding, N. Hamid, D.R. MacFarlane, M. Forsyth, C. Forsyth, C. Collins, J. 
Huang, Chem. Mater. 13 (2001) 558-564.

[93] W.A. Henderson, M. Herstedt, V.G. Young Jr., S. Passerini, H.C. De Long, P.C. Trulove, Inorg. Chem. 45 (2006) 1412-1414.

[94] C.M. Forsyth, D.R. MacFarlane, J. Golding, J. Huang, J. Sun, M. Forsyth, Chem. Mater. 14 (2002) 2103-2108.

[95] J.M. Pringle, J. Golding, K. Baranyai, C.M. Forsyth, G.B. Deacon, J.L. Scotta, D.R. MacFarlane, New J. Chem. 27 (2003) 1504-1510.

[96] J.M. Pringle, J. Golding, C.M. Forsyth, G.B. Deacon, M. Forsyth, D.R. MacFarlane, J. Mater. Chem. 12 (2002) 3475-3480.

[97] P.A. Hunt, Mol. Simul. 32 (2006) 1-10.

[98] J.N. Canongia Lopes, J. Deschamps, A.A.H. Pádua, J. Phys. Chem. B 108 (2004) 2038-2047.

[99] J.N. Canongia Lopes, A.A.H. Pádua, J. Phys. Chem. B 108 (2004) 16893-16898.

[100] J. de Andrade, E.S. Böes, H. Stassen, J. Phys. Chem. B 106 (2002) 3546-3548.

[101] J. de Andrade, E.S. Böes, H. Stassen, J. Phys. Chem. B 106 (2002) 13344-13351.

[102] J.K. Shah, J.F. Brennecke, E.J. Maginn, Green Chem. 4 (2002) 112-118.

[103] C.G. Hanke, S.L. Price, R.M. Lynden-Bell, Mol. Phys. 99 (2001) 801-809.

[104] C.J. Margulis, H.A. Stern, B.J. Berne, J. Phys. Chem. B 106 (2002) 12017-12021.

[105] T.I. Morrow, E.J. Maggin, J. Phys. Chem. B 106 (2002) 12807-12813.

[106] J.H. Antony, D. Mertens, T. Breitenstein, A. Dölle, P. Wasserscheid, W.R. Carper, Pure Appl. Chem. 76 (2004) 255-261.

[107] J.K. Shah, E.J. Maginn, Fluid Phase Equilib. 222-223 (2004) 195-203.

[108] N.M. Micaelo, A.M. Baptista, C.M. Soares, J. Phys. Chem. B, 110 (2006) 14444-14451. 
[109] S.U. Lee, J. Jung, Y.K. Han, Chem. Phys. Lett. 406 (2005) 332-340.

[110] Z. Liu, S. Huang, We. Wang, J. Phys. Chem. B, 108 (2004) 12978-12989.

[111] K. Dong, S. Zhang, D. Wang, X. Yao, J. Phys. Chem. A 110 (2006) 9775-9782.

[112] Z. Meng, A. Dölle, W.R. Carper, J. Mol. Struct. (THEOCHEM) 585 (2002) $119-128$.

[113] Y.U. Paulechka, G.J. Kabo, A.V. Blokhin, O.A. Vydrov, J.W. Magee, M. Frenkel, J. Chem. Eng. Data 48 (2003) 457-462.

[114] S. Tsuzuki, H. Tokuda, K. Hayamizu, M. Watanabe, J. Phys. Chem. B 109 (2005) 16474-16481.

[115] M. Salanne, C. Simon, P. Turq, J. Phys. Chem. B, 110 (2006) 3504-3510.

[116] L. Gong, W. Guo, J. Xiong, R. Li, X. Wu, W. Li, Chem. Phys. Lett. 425 (2006) 167-178.

[117] A.G. Avent, P.A. Chaloner, M.P. Day, K.R. Seddon, T. Welton, J. Chem. Soc., Dalton Trans. 1994, 3405-3413.

[118] J.F. Huang, P.Y Chen, I.W. Sun, S.P. Wang, Inorg. Chim. Acta 320 (2001) 7-11. [119] J.F. Huang, P.Y. Chen, I.W. Sun, S.P. Wang, Spectrosc. Lett., 34 (2001) 591-603. [120] P.A.Z. Suarez, S. Einloft, J.E.L. Dullius, R.F. Souz, J.J. Dupont, J. Chim. Phys. 95 (1998) 1626-1639.

[121] J.H. Antony, D. Mertens, A. Dölle, P. Wasserscheid, W.R. Carper, Chem. Phys. Chem. 4 (2003) 588-594.

[122] A. Noda, K. Hayamizu, M. Watanabe, J. Phys. Chem. B 105 (2001) 4603-4610.

[123] H. Tokuda, K. Hayamizu, K. Ishii, M.A.B.H. Susan, M. Watanabe, J. Phys. Chem. B 108 (2004) 16593-16600.

[124] H. Tokuda, K. Hayamizu, K. Ishii, M.A.B.H. Susan, M. Watanabe, J. Phys. Chem. 
B 109 (2005) 6103-6110.

[125] H. Tokuda, K. Ishii, M.A.B.H. Susan, S. Tsuzuki, K. Hayamizu, M. Watanabe, J. Phys. Chem. B 110 (2006) 2833-2839.

[126] T. Umecky, M. Kanakubo, Y. Ikushima, Fluid Phase Equilibr. 228-229 (2005) 329-333.

[127] Y. Saito, K. Hirai, K. Matsumoto, R. Hagiwara, Y. Minamizaki, J. Phys. Chem. B 109 (2005) 2942-2948.

[128] D. Nama, P.G.A. Kumar, P.S. Pregosin, T.J. Geldbach, P.J. Dyson, Inorg. Chim. Acta 359 (2006) 1907-1911.

[129] A.D. Headley, N.M. Jackson, J. Phys. Org. Chem. 15 (2002) 52-55.

[130] S.T. Lin, M.F. Ding, C.W. Chang. S.S. Lue, Tetrahedron 60 (2004) 9441-9446.

[131] A. Mele, C.D. Tran, S.H.P. Lacerda, Angew. Chem., Int. Ed. 42 (2003) 4364-4366.

[132] A. Mele, B. Vergani, F. Viani, S.V. Meille, A. Farina, P. Bravo, Eur. J. Org. Chem., 1999, 187-196.

[133] C.J. Dymek Jr., J.J.P. Stewart, Inorg. Chem. 28 (1989) 1472-1476.

[134] K.M. Dieter, C.J. Dymek Jr., N.E. Heimer, J.W. Rowang, J.S. Wilkes, J. Am. Chem. Soc. 110 (1988) 2722-2726.

[135] H.C. Chang, J.C. Jiang, W.C. Tsai, G.C. Chen, S.H. Lin, J. Phys. Chem. B 110 (2006) 3302-3307.

[136] S.A. Katsyuba, P.J. Dyson, E.E. Vandyukova, A.V. Chernova, A. Vidiš, Helv. Chim. Acta 87 (2004) 2556-2565.

[137] N.E. Heimer, R.E. Del Sesto, Z. Meng, J.S. Wilkes, W.R. Carper, J. Mol. Liq. 124 (2006) 84-95.

[138] E.R. Talaty, S. Raja, V.J. Storhaug, A. Dölle, W.R. Carper, J. Phys. Chem. B 108 
(2004) 13177-13184.

[139] R.W. Berg, M. Deetlefs, K.R. Seddon, I. Shim, J.M. Thompson, J. Phys. Chem. B 109 (2005) 19018-19025.

[140] Y. Umebayashi, T. Fujimori, T. Sukizaki, M. Asada, K. Fujii, R. Kanzaki, S. Ishiguro, J. Phys. Chem. A 109 (2005) 8976-8982.

[141] K. Fujii, T. Fujimori, T. Takamuku, R. Kanzaki, Y. Umebayashi, S. Ishiguro, J. Phys. Chem. B 110 (2006) 8179-8183.

[142] J.N.A. Canongia Lopes, A.A.H. Pádua, J. Phys. Chem. B 110 (2006) 7485-7489.

[143] M. López-Pastor, M.J. Ayora-Cañada, M. Valcárcel, B. Lendl, J. Phys. Chem. B 110 (2006) 10896-10902.

[144] L. Cammarata, S.G. Kazarian, P.A. Salter, T. Welton, Phys. Chem. Chem. Phys. 3 (2001) 5192-5200.

[145] C.D. Tran, S.H.De Paoli Lacerda, D. Oliveira, Appl. Spectrosc. 57 (2003) 152-157.

[146] K. Matsumoto, R. Hagiwara, Y. Ito, S. Kohara, K. Suzuya, Nucl. Instrum. Meth. B. 199 (2003) 29-33.

[147] R. Hagiwara, K. Matsumoto, T. Tsuda, Y. Ito, S. Kohara, K. Suzuya, H. Matsumoto, Y. Miyazaki, J. Non-Cryst. Solids 312-314 (2002) 414-418.

[148] C. Hardacre, J.D. Holbrey, S.E.J. McMath, D.T. Bowron, A.K. Soper, J. Chem. Phys. 118 (2003) 273-278.

[149] C. Hardacre, S.E.J. McMath, M. Nieuwenhuyzen, D.T. Bowron, A.K. Soper, J. Phys.: Condens. Matter 15 (2003) S159-S166.

[150] M. Deetlefs, C. Hardacre, M. Nieuwenhuyzen, A.A.H. Padua, O. Sheppard, A.K. Soper, J. Phys. Chem. B 110 (2006) 12055-12061

[151] S.M. Urahata, M.C.C. Ribeiro, J. Chem. Phys. 120 (2004) 1855-1863. 
[152] C. Rey-Castr, L.F. Vega, J. Phys. Chem. B, 110 (2006) 14426-14435.

[153] C.G. Hanke, R.M. Lynden-Bell, J. Phys. Chem. B 107 (2003) 10873-10878.

[154] C.G. Hanke, N.A. Atamas, R.M. Lynden-Bell, Green Chem 4 (2002) 107-111.

[155] R.M. Lynden-Bell, N.A. Atamas, A. Vasilyuk, C.G. Hanke, Mol. Phys. 100 (2002) 3225-3229.

[156] A. Chaumont, E. Engler, G. Wipff, Inorg. Chem. 42 (2003) 5348-5356.

[157] A. Chaumont, G. Wipff, Phys. Chem. Chem. Phys. 5 (2003) 3481-3488.

[158] Y. Shim, J. Duan, M.Y. Choi, H.J. Kim, J. Chem. Phys. 119 (2003) 6411-6414.

[159] D.D. Zorn, J.A. Boatz, M.S. Gordon, J. Phys. Chem. B, 110 (2006) 11110-11119.

[160] S. Takahashi, L.A. Curtiss, D. Gosztola, N. Koura, M.-L. Saboungi, Inorg. Chem. 34 (1995) 2990-2993.

[161] S. Takahashi, K. Suzuya, S. Kohara, N. Koura, L.A. Curtiss, M.-L. Saboungi, Z. Phys. Chem., 209 (1999) 209-221.

[162] C.G. Hanke, A. Johansson, J.B. Harper, R.M. Lynden-Bell, Chem. Phys. Lett. 374 (2003) 85-90.

[163] P.A. Hunt, I.R. Goild, J. Phys. Chem. A 110 (2006) 2269-2282.

[164] M.G. Del Pópolo, R.M. Lynden-Bell, J. Kohanoff, J. Phys. Chem. B 109 (2005) 5895-5902.

[165] M.S. Sitze, E.R. Schreiter, E.V. Patterson, R.G. Freeman, Inorg. Chem. 40 (2001) 2298-2304.

[166] O. Borodin, G.D. Smith, J. Phys. Chem. B 110 (2006) 11481-11490.

[167] M. Bühl, A. Chaumone, R. Schurhammer, G. Wipff, J. Phys. Chem. B 109 (2005) 18591-18599.

[168] T.G.A. Youngs, M.G. Del Pópolo, J. Kohanoff, J. Phys. Chem. B 110 (2005) 
5697-5707.

[169] M.G. Del Pópolo, G.A. Voth, J. Phys. Chem. B 108 (2004) 1744-1752.

[170] K.E. Gutowski, J.D. Holbrey, R.D. Rogers, D.A. Dixon, J. Phys. Chem. 109 (2005) 23196-23208.

[171] C. Cadena, Q. Zhao, R.Q. Snurr, E.J. Maginn, 110 (2006) 2821-2832.

[172] T. Yan, C.J. Burnham, M.G.M. G. Del Pópolo, G.A. Voth, J. Phys. Chem. B 108 (2004) 11877-11881.

[173] J.Z. Yang, Y. Jin, W.G. Xu, Q.G. Zhang, S.L. Zang, Fluid Phase Equilib. 227 (2005) 41-46.

[174] J.Z. Yang, P. Tian, W.G. Xu, B. Xu, S.Z. Liu, Thermochim. Acta 412 (2004) 1-5.

[175] B.L. Bhargava, S. Balasubramanian, Chem. Phys. Lett. 417 (2006) 486-491.

[176] C.K. Larive, M. Lin, B.S. Kinnear, B.J. Piersma, C.E. Keller, C.E.W.R. Carper, J. Phys. Chem. 102 (1998) 1717-1723.

[177] W.R. Carper, J.L. Pflug, J.S. Wilkes, Inorg. Chim. Acta 202 (1992) 89-93.

[178] N.E. Heimer, J.S. Wilkes, P.G. Wahlbeck, W.R. Carper, J. Phys. Chem. A 110 (2006) 868-874.

[179] I. Nicotera, C. Oliviero, W.A. Henderson, G.B. Appetecchi, S. Passerini, J. Phys. Chem. B 109 (2005) 22814-22819.

[180] M. Castriota, T. Caruso, R.G. Agostino, E. Cazzanelli, W.A. Henderson, S. Passerini, J. Phys. Chem. A 109 (2005) 92-96.

[181] H. Katayanagi, S. Hayashi, H. Hamaguchi, K. Nishikawa, Chem. Phys. Lett., 392 (2004) 460-464.

[182] K. Dahl, G.M. Sando, D.M. Fox, T.E. Sutto, J.C. Owrutskye, J. Chem. Phys. 123 (2005) 084504. 
[183] F.R. Trouw, D.L. Price, Annu. Rev. Phys. Chem. 50 (1999) 571-601.

[184] P.J. Dyson, J.S. McIndoe, D. Zhao, Chem. Commun, 2003, 508-509.

[185] S. Dorbritz, W. Ruth, U. Kragl, Adv. Synth. Catal. 347 (2005) 1273 -1279.

[186] N. Kuhn, M. Walker, M. Steimann, Z. Naturforsch. 57b (2002) 248-250. 